\title{
LO SOCIAL \\ en la vida y en el pensamiento ${ }^{1}$
}

\section{Leopold von Wiese}

INDICE: General (4).--I. Lo individual y lo colectivo (7-42): 1. Delimitación del concepto: lo social (7-8). 2. Contenido del concepto: lo social (8-10). 3. El yo (10-11). 4. La filosofía de los pronombres personales (12-13). 5. Lo inconsciente (13-16). 6. Los otros (16-19). 7. El par (diada) y el trío (triada) (19-26). 8. Los grupos mayores y los grandes grupos (26-31). 9. La masa (31-33). 10. Los círculos y la atmósfera social (33-35). 11. Las corporaciones (35-37). 12. La sociedad (38-41).- - II. El ámbito privado y público en la vida humana (43-74): 1. Observaciones previas (43). 2. La relación antagónica del ámbito público y del privado (43-47). 3. Aclaración de las palabras: público y privado; definición de ambos conceptos (47-51). 4. Dependencia y autonomía (51-54). 5. El sobrepoder de la public(o)idad (54-56). 6. La fama (57-61). 7. La profesión (61-68). 8. La economía del dinero (68-69). 9. El incremento de la población (70-72). 10. La tarea de la nivelación (72-74).--III. Anquilosamiento y plenitud como principios fundamentales de dos sistemas sociales (75-79): 1. Dos necesidades contrapuestas (75-76). 2. La tendencia al tránsito de la tesis a la antítesis (76-77). 3. Liberalismo (77). 4. El mundo occidental y oriental (78-79). 5. Los dos peligros para Occidente (79).

${ }^{1}$ Leopold von Wiese, Das Soziale im Leben und im Denken, Westdeutscher Verlag, Köln und Opladen, 1956. En el Indice colocamos para cada apartado, entre paréntesis, las páginas correspondientes al original alemán. También hemos adjuntado, entre paréntesis y en cursivas, algunos términos alemanes especialmente «intraducibles» o de contenido sociológico preciso. Los subrayados (en cursiva negra) son, por supuesto, del propio Wiese. Por otro lado, las notas a pie de página las reproducimos inalteradas, según aparecen en el original. Para más aclaraciones, o de cara a mayores detalles bibliográficos, remito a mi escrito de presentación de este ensayo. 


\section{LO INDIVIDUAL Y LO COLECTIVO}

\section{Delimitación del concepto: "lo social»}

Es preciso que un autor declare con la mayor claridad posible lo que entiende con el título de su libro. Con frecuencia, el lector vincula los términos sobre el tema, escogidos por el autor, con determinados prejuicios e interpretaciones que le van a acompañar en la sucesiva lectura pero que le son ajenos por completo al autor del libro. Por ello, si éste no declara desde el principio el sentido que da a las palabras del título pueden surgir confusiones y malentendidos fatales. He escogido el título de la manera más sencilla posible, pero el mismo contiene palabras de significado polivalente: ¡«lo social»! Advierto inmediatamente que he elegido con premeditación el neutro y no he dicho «la sociedad», la estructura social o los sistemas sociales. Ello hubiera entrado en contradicción con la idea fundamental que se extiende a través de todas las páginas que siguen.

La expresión «lo social» tampoco se equivale, de ningún modo, con una que resulta de exposiciones más limitadas sobre temas más o menos afines como, p. ej., «lo sociopolítico», entendido como lo comunitario, el bienestar, la asistencia social o la cuestión laboral.

Pero las expresiones «social» y «sociología» se han visto sometidas también a otro acotamiento - más en su uso cotidiano extracientífico y, sobre todo, desde la esencia de la prensa- que habría que evitar aquí: con alguna frecuencia, parece como si el ámbito de lo social abarcara tan sólo a los estamentos y las clases, de modo que si alguien habla desde el punto de vista sociológico se entiende en el estrecho sentido de que adopta una óptica dirigida a explicar la formación de capas sociales dentro de un pueblo. Por supuesto que todo esto es esencial y el sociólogo debe ocuparse de ello; pero no constituye sino una parte dentro de un campo suyo de trabajo mucho más amplio.

Con «lo social» nos referimos a algo mucho más general, fundamental, antropológico por antonomasia. Queremos —es mi propuesta- adentrarnos en las cuestiones nucleares de la existencia humana, las que por su significación (que atraviesa todo nuestro ser) colocan en un plano muy lejano a cualquier problema puntual sobre la configuración organizativa de la vida pública actual.

En realidad, no hay para el hombre sino tres núcleos de problemas esenciales: su relación con la deidad, lo que es decir las cuestiones religiosas; siguiendo con la configuración de su vida interior — la constitución del alma y del espíritu-, para acabar precisamente con «lo social», o sea, con la conexión entre los hombres. Las tres áreas de problemas mantienen una múltiple dependencia; en cuanto dominios científicos, teología, psicología y sociología se completan. Pero si bien es muy necesario no desconsiderar ni en la vida ni en el pensamiento esta vinculación y buscar finalmente una síntesis que corone esos tres ámbitos, también es importante no confundirlos conceptualmente en 
los análisis previos, sino, por el contrario, elaborar mediante un proceso de isolación aquello de lo que se trate en cada uno de los tres casos. Por supuesto que durante esta tarea los resultados y observaciones obtenidos desde un dominio ayudan en la investigación del otro. También es cierto que la esfera religiosa se nos queda en ello un tanto al margen, pero una teología que trabaje científicamente tampoco podrá prescindir del análisis de la interioridad humana. Las cuestiones de la convivencia entre los hombres se tornan insolubles si no profundizamos en el ámbito de la psyche, de igual modo que una buena parte de la psicología no puede obviar los resultados de la exploración de las relaciones entrehumanas ${ }^{2}$. Pero las cuestiones fundamentales que no hay que perder de vista son distintas. Allí, desde la exploración del alma: ¿qué acontece en el interior del hombre?; aquí, en cambio: ¿cómo actúan unos hombres sobre otros? Al investigador sólo le concierne aquello de entre los resultados de otros campos que no pueda eludir si quiere esclarecer la problemática del suyo. En ocasiones, éste tiene que hurgar en los ámbitos vecinos aún más profundamente que los propios especialistas, ser más psicólogo que sociólogo o más sociólogo que psicólogo; pero volverá a arrodillarse ante su otro altar. Simplemente dicho: aquellas observaciones son para él tan sólo un material, no su objetivo obligado. A menudo, el sociólogo debe hablar del alma, del espíritu y del cuerpo del hombre, pero sólo porque se constata la necesidad de que exista una Antropología (entendida la palabra en el sentido más amplio, no sólo en un sentido meramente científico-naturalista), si ha de darse Sociología alguna.

No es siempre fácil atenerse a la exigencia de dejar algo de lado en sus fundamentos y, sin embargo, reasumirlo en la exposición, reconciliando con ello los dos enfoques contrapuestos.

\section{El contenido del concepto: «lo social»}

He anticipado todo lo anterior porque creo que así puede quedar más claro el significado que damos aquí al término «lo social». Con él me refiero a todas y cualquiera de las actuaciones (Einwirkungen) que partiendo de un hombre se ejercen sobre otro hombre o sobre las mayorias humanas, asi como, viceversa, las que se ejercen desde estos constructos sobre las personas. La preposición que

2 Nota del traductor: El viejo (altmodisch) y «magistral» idioma alemán empleado por Wiese nos obliga a hacer aquí unas mínimas aclaraciones básicas. El término alemán en singular es el de zwischenmenschlich. Habitualmente es traducido como «interhumano». Sin embargo, se ajusta mucho mejor a la estructura semántica y sintáctica del texto - teniendo en cuenta tanto las principales pretensiones teóricas de Wiese como los múltiples énfasis explícitamente terminológicos que impone a sus escritos desde su «relacionismo sociológico»— hacer su traducción desde un castellano que recurra también directamente a la preposición «entre», es decir: zwischen. Aun pudiendo parecer un tanto atípica, la traducción realizada aquí es la que mejor refleja tanto el espíritu como el tono discursivo de Wiese y la que permite mostrar adecuadamente las características de su peculiar esfuerzo conceptualizador. Así, frente a la traducción más habitual de Einwirkung por «influencia», hemos preferido la de «actuación». 
mejor explica relativamente semejantes relaciones es «entre» y que sólo tiene el inconveniente de que también se usa en sentido contrario al mencionado. Cuando se dice que algo acontece «entre» dos hombres puede uno precisamente dar a entender que es algún tercer elemento extraño que se erige entre ellos (en este sentido: que se constituye entre ellos) el que les mantiene alejados entre sí. Precisamente es a esto a lo que no nos referimos, sino a lo que son las fuerzas mismas que de A transitan a B. Pero éstas no son sólo fuerzas agregadoras, conexionantes, sino también fuerzas de la disgregación, que provocan la disolución, la separación. Por eso no podemos utilizar, en vez de la expresión «entre sí», la de "mutuamente», porque sólo remitiría a las fuerzas — digamos- de la agregación en positivo, de la congregación.

Si en lugar de la palabra «social» usamos el término equivalente de «entrehumano", entonces ello nos exige que lo interpretemos en el sentido que acabamos de indicar; a la hora de su aplicación tenemos también que evitar otras dos acepciones unilaterales del mismo; por un lado, la que comete el error de quedarse sólo con las relaciones interpersonales: desatenderíamos entonces la circunstancia de que, a partir de las relaciones entrehumanas, surgen, por distintas vías, grupos (tomada la palabra — grupo- en ese su significado más amplio mediante el que ésta se vuelve equiparable a la de colectividades, mayorías o conjuntos), y que semejantes constructos sociales ejercen la mayor influencia sobre las meras relaciones; una teoría de los vínculos sociales abarca, pues, esos constructos. El otro error, prevalente hoy, es opuesto al anterior: tomar por objeto, cuando nos ocupamos de lo social, sólo a las colectividades; de manera que la Sociología se reduzca a mera teoría de los grupos, dejando al margen a la interdependencia existente entre "yo» y "tú", a la red de los procesos sociales en formación. Nosotros explicamos los constructos partiendo de los procesos sociales que les preceden o que con ellos se despliegan, pero no dejamos de tener en cuenta que el ser mismo de la presencia y efectividad de los constructos influye, a su vez, de nuevo sobre los procesos sociales.

Confundiríamos la Sociología con un rechazable sociologismo si pretendiéramos ampliar el campo de las fuerzas sociales en detrimento de los poderes individuales. Por importante que sea para nosotros «lo social», de ninguna manera podemos reducir los procesos que tienen lugar en el alma de cada individuo a meras reacciones maniobradas desde el exterior; los hechos de la vida psíquica de los hombres seguirán siendo siempre, propiamente y en última instancia, lo decisivo. El sociólogo no debe dejar en manos exclusivas del psicólogo la consideración del cómo el alma y el espíritu asumen los influjos del mundo entorno, ni del cómo la voluntad reelabora esas representaciones de las imágenes en actos. Con razón nos enseñó $C$. $G$. Jung a buscar en las pulsiones inconscientes aquello que guía la acción.

De ello hablaremos luego. Por lo pronto y acerca de «lo social»:

Los sucesos que yo resumo en este término constituyen un círculo sin principio ni fin; la serpiente se muerde la cola; ello dificulta la representación de lo social: ¿tenemos que arrancar de un principio para culminar, tras un desarrollo 
progresivo, en una cima o, a la inversa, descendiendo de los constructos más embarullados y complejos, llegar a los contactos entre personas individuales particulares? ¿Por dónde empezar entonces?

He escogido el camino que me parece relativamente más seguro, esto es: el que me desvíe lo menos posible hacia especulaciones y afirmaciones indemostrables por ser el que más de inmediato se puede comprobar en experiencias efectivas; el que lleva de lo concreto a lo abstracto; el camino que va desde el individuo de carne y hueso — desde el «yo» perceptivo y sentiente, que experimenta sufrimientos y alegrías - hasta los constructos sociales meramente representados, asentados en el mundo de las ideas; en definitiva, hasta el estado, el pueblo, la iglesia, el círculo cultural, la humanidad.

Cierto: la afirmación de que el "yo» sea lo concreto y un a modo de quantum que surge listo y clausurado en el círculo de lo social precisa de una interpretación restrictiva. Por de pronto, recuérdese la mencionada maraña de relaciones recíprocas que hace que el «yo» esté expuesto permanentemente al influjo de las fuerzas sociales y que, por lo tanto, jamás se halle como un ser ya «listo» en el comercio entrehumano.

\section{3. $E l \ll Y o »$}

Tras estas observaciones delimitadoras querría atreverme a escoger como punto de partida en mi ocupación con «lo social» el «yo»: esto es, y por lo pronto, cada persona en particular ${ }^{3}$; lo que suele denominarse con el aborrecible término de individuo. Digo aborrecible porque suscita la representación de una especie de mecanismo que se anuncia a sí mismo como totalidad y nos aleja de la imagen de un ser vivo y sensorial. Ni tampoco puede decirse que la impartibilidad (valga la expresión) sea una característica del ego; si bajo cierto punto de vista se nos puede aparecer como una totalidad circunscrita por la piel del cuerpo, bajo otro punto de vista se nos desgarra más bien su naturaleza en múltiples partes; el individuo se nos convierte en dividuo (Dividuum).

Por eso hace ya tiempo que propuse reemplazar un nombre tan áspero y falso como ése por el de «singular» (Singulare), justo porque para el sociólogo el problema fundamental estriba en su contraposición al plural de la mayoría humana.

3 Nota del traductor: El término Einzelne —que entre el amplio elenco terminológico empleado por Wiese es el más abstracto e incluyente- pensamos que ha de verterse al castellano con la locución de «individuo-particular»; o, mejor aún, con la de "particular-individuo", resaltando así más las nociones de "partícula» y de «indiviso", a la vez que se nos sugiere esa significación coloquial castellana que se le confiere al término cuando se emplea para tratar de caracterizar a una persona como «personaje», en tanto que «individuo-peculiar» o «individuo-singular». En las líneas que siguen, así como en el resto del ensayo, se verá cómo todo este entramado semántico se encuentra, además, detrás de las categorizaciones teóricas wiesianas, lo que nos obliga, por lo demás, a seleccionar en cada caso muy cuidadosamente cada vocablo de nuestro idioma entre sus sinónimos u homónimos. 
Otras denominaciones que podrían escogerse, aptas para determinadas consideraciones pero no para todas, serían las de: hombre (Homo), uno mismo (das Selbst), persona o, especialmente, la persona-particular (Einzelperson) o el hombre-particular (Einzelmensch). El hecho de que este hombre-particular posea el carácter de «ser único» (o singular) podría llevarnos a error, ya que semejante "único» es un tipo de ser viviente que se da entre millones de ejemplares y que comparte características muy esenciales (Artmerkmale) de una especie con otros hombres; semejante singular está muy lejos, en muchos aspectos, de ser "único», siendo más bien intercambiable: todo ello debería prohibirnos el uso de tales denominaciones, al menos mientras no hayamos aclarado un poco más el complejo problema de las relaciones, en la existencia humana, entre lo singular y lo plural. Pero, a falta de denominaciones con significado más estricto, bastaría con que al usar "yo», "persona», "hombre-particular», pensáramos en esa especie de viviente biológicamente determinable que se nos ofrece a la percepción en la figura de cada uno de nosotros «homines» y que cada cual experimenta en sí mismo de la manera menos mediatizada, justo como "yo». En este sentido, antes de adentrarnos en lo social, nos hemos de ocupar en primera instancia del «yo».

Desde hace muchos siglos, el «yo» ha sido uno de los objetos más tratados por la filosofía y cuya investigación, o determinación conceptual sin más, se ha ido haciendo más embrollada y compleja. Superaría mis fuerzas con mucho la pretensión de informar aquí en su totalidad sobre las teorías del "yo»: rompería el marco de este pequeño escrito. Erwin Metzke enumera en su Handlexikon der Philosophie hasta doce concepciones diferentes. Si se las pone a prueba habría que reconocer que ninguna es indispensable. Pero aquí, como en los estudios más profundos y exhaustivos de los grandes pensadores - Aristóteles, Agustín, Hume, Hobbes, Kant, sobre todo; los idealistas (Fichte en particular); los modernos como Freud, C. G. Jung, Rothacker, Lersch, Holzschuher (por sólo citar algunos entre muchos)_, nos encontramos siempre con una lucha desesperada por aprehender la configuración constantemente huidiza y fantasmal de este "yo», sin conseguirlo; apenas si se pueden aprehender determinados rasgos y características que, en efecto, resultan ser correctas e ilustrativas; pero no hay modo de lograr, con la seguridad y claridad del pensamiento discursivo, una visión conjunta del «yo» conceptualmente delimitada. El «yo» se anuncia pero sigue escondido. Hecho inquietante que no debería llevarnos a su negación. Justo lo más esencial, que determina nuestra vida, resulta ser siempre lo más indefinible. Ha de bastarnos con aprehenderlo en sus formas de anunciarse. Desde ellas el yo se convierte en algo cotejable, además de que esas mismas expresiones (Bekundungen) pueden también al ser confrontadas conceptualizarse de un modo inteligible.

Para la tarea que nos hemos asignado no es necesario en absoluto ir tras todas esas manifestaciones del yo tan fuertemente detectable en la intuición y en los sentimientos; nuestra participación en el mismo alcanza tan sólo en lo que remite a la relación (Verhältnis) del yo, del singular (es precisamente el yo 
el que nos amarra en tanto que singular), hacia el otro o los otros hombres. Ya en esta óptica sociológica se nos ofrecen numerosas posibilidades de excavar canales que penetran profundamente en la figura, indescriptible como un todo pero efectiva, del yo.

\section{La filosofia de los pronombres personales}

A los problemas básicos de la Sociología se les podría designar como filosofía de los pronombres personales: ¿cómo se las ha el yo respecto del tú, nosotros, vosotros, ellos, ello (Es)? El empleo de la palabra "yo" es el que hace al niño aprender a manejarse paulatinamente con corrección, donde se expresa básicamente la impresión o la conciencia de que el hombre, circunscrito por la piel de su cuerpo y por ello perceptible, se diferencia desde su internalidad de su mundo entorno. El yo es detectable merced a su distancia del tú. Más confusa e intransparente es la relación al nosotros; constituye el objeto fundamental de la psicosociología. Tiene, por lo demás, su importancia el si lo que se opone al yo como partner es simplemente el tú singular o el vosotros. Menos subjetivo, más bien rayando en lo objetivo, es la distancia del yo respecto de la tercera o terceras personas, que encuentra su expresión en palabras tan simples como «él/ella» (en singular) o «ellos/as» (en plural).

Desde Freud se habla mucho del "ello» ("Es»). Se enseña que, subyaciendo a la parte consciente del alma humana, se halla el llamado «ello»; se reserva así el uso de la palabra "yo» a la región superior de la conciencia entendida casi siempre como el reino de la Ratio, no quedando claro si abarca también a los sentimientos más elevados.

Se trata, por tanto, de la teoría, rica en problemas, de la estratificación del alma humana. De nuevo nos hallamos ante una antítesis: ¿constituye el hombre una unidad o se halla escindido en regiones que se completan o incluso compiten entre sí? Sólo hay una respuesta: ambas cosas. La percepción externa y la dependencia social — que responsabiliza siempre de sus actos a la persona en su conjunto- nos muestran que existe la unidad personal. Pero semejante persona, aparentemente tan cerrada, se nos brinda al análisis a través de diferentes planos que deberían ocupar al sociólogo, puesto que éste precisamente se interesa por las relaciones del yo con los demás hombres (del presente o del pasado).

En principio hay que distinguir bi- y tri-polaridad. Sin embargo, no es raro amontonarlas confusamente. La división bipartita cuerpo/alma parece la más inmediata y sencilla; lo que no impide que se plantee la archidebatida cuestión de si no constituyen una unidady, en todo caso, son expresiones de la vida estrechamente enlazadas entre sít. Con la tripartición - alma, cuerpo, espíritu- se complica el problema al asocisarse aquélla con la cuestión sobre la

${ }^{4}$ Cfr. «Leib, Seele und Geist», en el revisado 3. ${ }^{\text {er }}$ capítulo de mi Homo sum, Jena, 1940. 
validez y la valoración jerárquica de nuestras facultades de sentir, querer, representar y pensar. Rehúyo entrar en semejante problemática y me limito a afirmar la siguiente tesis: sentir, pensar, querer y fantasear se imbrican entre sí y no son sino manifestaciones de una sola y misma fuerza espiritual; pero, a la hora de la investigación científica, es necesario separarlas artificiosamente. Es descaminado adscribirles una escala valorativa. Se dan sentimientos más elevados respecto de los que el intento de abarcarlos inteligentemente en toda su riqueza resulta lamentable y vano; pero existen también productos del poder del pensamiento cuya claridad deja muy lejos a los sentimientos, con frecuencia evanescentes, que les acompañan; y hay imágenes de la intuición fantasiosa que dejan en ridículo al lenguaje vinculado a la capacidad de pensar. En fin, la voluntad, detonante de la conducta, depende por completo, es verdad, de sentimientos y representaciones, lo que no quita para que en ocasiones luche por una autonomía enérgica frente a los otros influjos interiores.

Pero esta especie de estratificación —mal llamada así en cuanto implica alto y bajo: espíritu, alma y cuerpo- en nada se parece a la contraposición consciente/inconsciente, o a la tripolaridad consciente/semiconsciente/inconsciente. El problema capital estriba aquí en el esclarecimiento del inconsciente y la estimación de su influencia en la conducta humana.

\section{Lo inconsciente}

Lo inconsciente queda concebido usualmente como una dimensión profunda de la vida anímica que actúa en el hombre pero que escapa al control y dirección de su inteligencia y voluntad. Usando imágenes: en el plano superior de la conciencia las experiencias del yo son elaboradas con cierta claridad y delimitación; lo inconsciente, en cambio, se detecta fundamentalmente en las figuraciones del sueño.

De inmediato surge la cuestión: ¿de dónde toma lo inconsciente su contenido? C. G. Jung lo contempla como una herencia de las experiencias de los antepasados; contendría expresiones del alma colectiva. Para referirse a ellas acuñó el más bien confuso término de «arquetipos». Semejante vía de esclarecimiento de los procesos vitales de la persona profunda (Tiefenperson) ha de reclamar de manera especial la atención del sociólogo en la medida que esos procesos en el alma de cada hombre-particular son expuestos en conexión con los constructos vitales (Vitalgebilden) de un pasado hondo, con las razas originarias y la existencia prehistórica. Estéticamente visto, este anclaje de la vida interior individual en experiencias de la humanidad, hace tiempo desaparecida, tiene todo el encanto de la mística. Sobriamente mirado, debemos reconocer que los impulsos, impresiones y representaciones dependen de las experiencias de los antepasados; dependencia que se extiende a la vida afectiva más consciente. De otra parte, esa capa del alma a la que se le denomina inconsciente no está constituida sólo por representaciones colectivas; se nos muestra demasiado diferenciada 
de hombre a hombre para que ello pudiera ser así; la fuerza con que se expresa no es sólo una potencia primitiva, animal; sino que se sostiene sobre una noción del porvenir cargada de sombras; e incluso sobre lo extraterrenal, sobre aquello que se extiende mas allá de los confines de nuestra experiencia. Pero no quiero recaer yo mismo en la mística; me basta la sospecha de que el intento que hace Jung por esclarecer lo inconsciente se queda corto.

Ludwig von Holzschuher va por otro lado5. Rechaza la indivisibilidad y se apunta a la teoría de la bipolaridad del homo. Distingue un «potencial» racional y otro primitivo (Ichbewusstsein und Primitivbewusstsein), pero rechaza la dicotomía freudiana yo/ello. En realidad, ocurre que el esquema básico: aquí consciencia, allí inconsciencia, es insuficiente. El potencial primitivo sería primigenio, vital, pero también simple, retrasado y menesteroso. (Para decirlo de igual manera: esta caracterización de Holzschuher, no siempre consecuentemente mantenida, me parece ser también insuficiente.) Pero no sería la persona-yo (Ichperson) la que poseería el papel dominante; la persona primitiva (Primitivperson) tendría su propio ámbito de conciencia y no se identificaría plenamente con lo inconsciente; la persona-yo $y$ la primitiva tienen, respectivamente, una distinguible vertiente de consciencia y otra de inconsciencia. La conciencia no es el alma, sino un efecto (Wirkung) de lo anímico; también el yo tiene su lado inconsciente ${ }^{6}$. No es que Holzschuher separe a los hombres en yos racionales y personas primitivas; se trata más bien de una polaridad que se da en cada homo con grados de intensidad muy diversos y variables.

Por mi parte, rechazaría el término "primitivo», más adecuado al penoso orgullo de no pocos intelectuales, pagados de su ratio, que a la concepción, axiológicamente neutral, de Holzschuher. A este propósito tengo escrito: «La razón se me antoja más bien enemiga del yo; ordena las manifestaciones espontáneas de la naturaleza humana en esquemas que el entendimiento ha creado al servicio de la utilidad práctica. Desde luego, no querría caer en la moda de denigrar el entendimiento y la inteligencia (el caudal intelectual del nuevo cerebro); pero determinadas operaciones mentales me parecen mucho más "primitivas" que determinadas fuerzas afectivas emergentes de la profundidad del abismo anímico.»

Personalmente, me he reconocido en Homo sum partidario de la unidad de la persona humana: «no hay proceso mental que surja sin el acompañamiento de sentimientos, representaciones imaginarias e impulsos de la voluntad ${ }^{7}$. He hablado de las manifestaciones triunitarias del yo, aunque en busca de una dicotomía de otro tipo, explicando: "preferimos hablar de dos esferas siempre que no se confundan ni con la contraposición naturaleza/cultura, ni con la de physis/psyche, ni, sobre todo, la de espíritu/alma ${ }^{8}$. Pretendo trazar la distinción

Ludwig v. HolzschuHer, Praktische Psychologie, Seebruck am Chiemsee, 1949; 2. ${ }^{\text {ed., }}$ 1955.

${ }^{6}$ Cfr. mi recensión en la Kölnischer Zeitschrift für Soziologie, 3 Jahrg., pp. 246 ss.

O. c., p. 68.

${ }^{8}$ O. c., p. 70. 
entre una esfera universal o normal de lo vital y una esfera de vitalidad más elevada y desacostumbrada. A esta segunda la llamo "ingenio" (Ingenium). Comparando esta bipartición con la bipolaridad de Holzschuher se echa de ver una diferencia esencial: el ingenio no se identifica con el dominio de la razón ni la esfera normal con el potencial primitivo. Más bien, logos y eros se encuentran unidos en el ingenio; en cuanto a la esfera normal (expresión desgraciada) se caracteriza porque o el impulso emocional, o el instinto, o la inteligencia, o la ideación (Scheler) son en exceso débiles cuando no pálidas e inconsistentes. Me gustaría destacar la unidad de la vitalidad, que se puede expresar también en el pensamiento, frente a la escisión del yo; pero, según dije, distinguiendo entre una vitalidad más elevada y otra más mediana (durchsnittlich-matter). Con lo que, sin menospreciar a la ratio, tampoco se la exalta a un grado más refinado de la vida interior».

Lo que pretendo con ello, desde el punto de vista sociológico, es resaltar la importancia, para la vida social, de la personalidad fuerte, del singular destacado que se alza por encima de la media de la masa humana. (En qué ámbitos de la partición espíritu/corporal se hace valer semejante vitalidad: si emocional, fantasiosamente o de manera volitiva e inteligente, es problema aparte.) $\mathrm{Me}$ desagradaría caer, como Carlyle o Nietzsche, en el endiosamiento del superhombre, de modo que los pueblos no pasarían de ser un rodeo para su surgimiento; los "genios" tienen sus defectos y con frecuencia dan no poco trabajo a los psiquiatras ${ }^{9}$. Pero más preocupante aún que glorificarles es denigrarles: reducirlos en el fondo a mero instrumento pasivo de los colectivos, de las masas, de manera que las verdaderas fuerzas que empujan la evolución residirían en ellas y no en los individuos fuertes. Estos, si es caso, tendrían un oído afinado para los esfuerzos latentes en los constructos sociales: simplemente desatarían su potencial, en busca de ejercicio y realización. Tampoco es menos cierto que si los empeños de los (por usar la expresión de G. Tarde) inventeurs no conectan con las necesidades, explícitas o latentes, de las grandes mayorías ni se corresponden con las tendencias de la época y de cada pueblo, su efectividad quedará cuestionada. Hay diferencias destacables entre inventeurs e imitateurs; a menudo el gran agitador apelará en vano a impulsos que los más aún no comprenden; en ocasiones muere antes de que se detecte su influjo; no es raro que tenga éxito en otro lugar; pero hay que construir algún puente, y esto es, cuando menos, el trabajo de los hombres creadores.

¿Hay alguna vinculación lógica entre la división - yo normal/supranormal- que acabamos de hacer y la teoría psicológico-individual de la estratificación bi o tripartita del alma? No sólo empalmamos aquí la consideración sociológica con aquella que estudia el alma; la conjunción se da también en el dominio psicológico: las capacidades de los supranormales ahondan en lo profundo del alma y desde allí impregnan la superestructura del ámbito racional.

9 Cfr. Wilhem Lange-Eichbaum, Genie, Irrsinn und Ruhm; eine Pathographie des Genies, 4. ${ }^{\mathrm{a}}$ ed., München und Basel,1955. 
Todo lo que llamamos don para la intuición o el ingenio no enraiza en el aparato de la razón lógico/concluyente, sino en lo que se denomina hoy, abusivamente, con la palabra «irracional». Pero, como dijimos, no deberíamos separar la persona conjunta en capas excluyentes; más bien, los sentimientos y la fantasía participan de la fuerza del ingenio e irrumpen desde allí hasta la ratio. Depende mucho de la división social e histórico-espiritual del trabajo en especialidades (arte, ciencia, religión, política, economía, etc.) el que se haga valer más el principio de lo racional o de lo afectivo y perceptivo.

Al yo le es esencial su mismidad aislada. Salvo que la esquizofrenia u otras enfermedades análogas lo impidan, sentirá que su cuerpo, su espíritu y su alma le pertenecen; los dolores y los gozos de su cuerpo y de su alma los siente como propios y sólo por él detectables; sin embargo, los cuerpos y las almas de los otros hombres son un mundo extraño del que apenas se puede formar, gracias a reiteradas sensaciones, más o menos fatigosa e imperfectamente, una idea las más de las veces también imperfecta. El yo es solitario. Nos damos cuenta de que las impresiones, barruntos, deseos y, sobre todo, temores que en determinados momentos nos invaden no son participados por los hombres que nos rodean; de que nos encontramos absolutamente solos «en nuestro nicho materno" (mutterseelenallein), en un mundo que no participa en nada de todo ello; y quienes así lo sienten se llenan de tristeza. El hombre tiene que morir en soledad; los espantos de la hora de la muerte por los que atraviesan tales o cuales, aunque no todos, ponen en evidencia nuestro último, profundo abandono. A muy pocos les es dado soportar tan alto grado de soledad del yo. Cuanto más les hayan desplazado aquellos que les sobreviven, más se agarran muchos a la esperanza de un mundo trascendente, a la redención del yo culpable. Y al desaparecer este mundo perceptible busca el moribundo acceso a otro suprasensible: en cualquier caso, querría escapar al estremecimiento que habita en la soledad.

El impulso básico hacia la comunidad enraiza en la vida misma en la exigencia de no quedarnos solos. A primera vista, parece tener éxito la vida en común; incluso se diría que hoy es hasta tal punto la regla que el hombre sensible suspira por estar a solas consigo mismo y llega a experimentar, en ocasiones al menos, el placer de aislarse de cualquier tipo de compañía. Es verdad que la soledad genera el trato con dudas, fantasías o deseos de perfección, cuando las neurosis no despiertan espectros demoníacos; de modo que el corazón compungido reclama de nuevo ser librado de una soledad a cuya altura no se encontraba.

Sólo una fuerza espiritual puede liberar al yo del tormento de la soledad: el amor. Su auténtico gozo consiste, valga decir, en tener la certidumbre o hacerse la ilusión de poder adentrarse en la con-pasión (Mitempfinden) de una criatura. Lo decisivo no es sólo el convencimiento de que hombres de otro tipo sienten «con» el propio yo, sino el que se desarrolle la capacidad misma de sentir al otro yo como equivalente al de uno; y es la fuerza con la que se hace valer esta común soledad verdadera y profunda la que nos hace conscientes de lo aban- 
donado que se encuentra, en el fondo, el hombre que no ama. Esto vale también para el sexo y eros.

El amor sexual anula la soledad del cuerpo. En las confesiones del estafador Felix Krull (también en algunos pasos de su Doktor Faustus) lo ha dibujado con gran elocuencia Thomas Mann. Recuerdo el diálogo del genial lebrel Felix con su Zouzou, en el que, entre otras cosas, observa lo siguiente: "Es verdad: el hombre vive aislado y separado en su piel no sólo porque deba, sino porque no quiere que sea de otro modo. El otro, cualquier otro bajo su piel, le resulta en realidad repelente y sólo la persona propia, exclusiva y única, no le es repugnante. ¿Y qué es lo que, para asombro del mundo entero, elimina la separación entre una corporeidad y otra, entre yo y tú? El amor. Es la proximidad, la más próxima proximidad, tan sin fronteras como sea posible, justo aquella proximidad que bajo otra circunstancia resultaba ahogante hasta la asfixia.»

Pero es esta maravillosa transformación de la náusea ante el cuerpo de otro hombre en la exigencia de unión de los cuerpos la que pone de manifiesto la frecuente interdependencia de sexo y eros. También las almas se afanan por unirse. Al hacerlo buscan con frecuencia mucho menos la igualdad de metas de sus sentimientos y representaciones que la mutua complementación, perfeccionamiento y justificación. Siempre, la ruptura de la soledad se vive como una liberación de lo maldito, como una maravillosa realización del propio ser. El otro o la otra no es ahora ya el adversario insensible y a combatir, sino el salvador.

Sería ir demasiado lejos si pretendiéramos ahondar más en las exteriorizaciones de este triunfador sobre la prepotencia de la soledad que es el amor. De otro modo tendríamos que mencionar cómo la cabal fuerza de la salvación por el amor choca contra múltiples obstáculos tanto en el sexo como en eros. Apenas si puede desplegar toda su capacidad idealizadora en un breve espacio de tiempo. El amor sexual es sobre todo un hijo del instante, si bien las más de las veces se recupera tras su desencanto. Pero también la comunión anímicoespiritual tiene que volver a luchar enseguida contra el tirón hacia la soledad y, con ella, hacia la separación. La renovada crítica al tú puede llevar a hombres fácilmente influenciables a tener por ilusa o, cuando menos, exagerada la sublimación que supone la entrega; siendo de ánimo variable acrecientan ante sí y ante la pareja su desengaño, lo viven como desaliento e intentan romper la unión; el amor se les antoja engaño. Quienes tienen más en cuenta las carencias de la naturaleza humana y saben que hay que cultivar y cuidar muy bien sus ventajas, no ignoran que la permanencia de la tormentosa pasión del primer estadio no está garantizada por la fuerza de la voluntad; pero que es posible, aun cuando regrese o continúe un resto de soledad individual, hacer que dure no poco de la intimidad y veracidad del amor.

También la amistad es una fuerza que atenúa la mismidad del yo. Cuando penetra en las almas en las que mora el eros vale para ella lo que vale para el amor. Por regla general, sólo resuelve la situación de soledad en lo que se refiere a los planos más superficiales de la vida. Es un alivio precioso y estimulante 
en la lucha diaria por la existencia, en la profesión, en casa y en la vida corriente. Allí donde, por lo demás, se enfrentan intereses bajo la forma de una lucha concurrencial, la amistad tiende un puente a esta confrontación y convierte en propio lo ajeno. La simpatía es el sentimiento que la sustenta; mediante aquélla, uno se da cuenta de que, pese a todo, no hay una extrañeza radical entre el yo y el tú; de que es posible aligerar la soledad del esfuerzo en la vida social; y de que no hay que estimular y apoyar el trabajo de los otros sólo porque una organización adecuada de la comunidad laboral sea más eficiente, sino porque así el esfuerzo del otro o de los otros puede quedar justificado tanto como el de uno mismo. Se rompe así la soledad en el ámbito de la actividad exterior. Hasta qué punto el calor de una camaradería voluntariamente dispensada sea capaz de lograr, además, una superación de la profunda soledad del yo, es algo que no puede afirmase con carácter general. Pero, en cambio, la circunstancia de que no sea tan cálida como la erótica la preserva también con mayor frecuencia de la repentina demolición a la que se ve sometido el amor; suele ser más consistente y suaviza las asperezas de la pelea en pro/contra tan propias de éste. La amistad aminora la soledad; pero justo porque sentimos que la mano consoladora del hermano o de la hermana mitiga pero no nos libera del abandono es por lo que éste se nos manifiesta a veces con más fuerza en el fondo de nuestra alma.

Cuanto venimos diciendo sobre el amor y la amistad no vale sino para los supranormales. Se requiere una cierta fuerza de ánimo que no es común. También los más barruntan la fuerza opresiva o gratificante de la soledad, pero en menor medida; y, en todo caso, no en el trajín de la cotidianidad. Cierto: sienten su carga instintivamente acaso con más fuerza que aquéllos; pero disponen de numerosos medios para ahogar tal sentimiento. Su vida exterior e íntima transcurre en la superficie de la existencia de la que ya hablamos. No consienten a su yo que se desarrolle con autenticidad y autonomía, sino que buscan disolverle en la figura refleja de su ser social. Son lo que el entorno hace de ellos. La compañía y/o el trabajo no dejan aflorar los efectos de la soledad. Esta no es para ellos ningún problema. La confunden con el aburrimiento. Cuando se aburren, lo que acontece con frecuencia, escapan rápido en busca de relaciones tan múltiples como superficiales con otros hombres; hacia los grupos pequeños sobre todo. El eremita les resulta ininteligible; su hogar se halla entre las grandes multitudes: en los campos de deporte o en las concentraciones populares.

\section{El par (diada) y el trío (triada)}

Con las reflexiones sobre la soledad me he plantado ya de lleno en la segunda cuestión: ¿qué pasa con el «él», o «los», otro/s? Por lo pronto, no queremos aún reflexionar sobre los partners en los grupos que rebasan numéricamente la relación a dos, sino, justo, sobre el grupo par y, con él, en los otros. 
La denominación «el otro» resalta la diferencia: el ser-otro; en la palabra "par», en cambio, la idea de que hay también un «anti-par» en el que dos hombres están unidos por ciertas fuerzas cede el paso a la de unidad y complementación. La "otridad» nos hace presente que, a menudo, en la relación a dos la tendencia a la contraposición es más efectiva y originaria que la inclinación a formar pareja en sentido positivo; esto es, para ayudarse, apoyarse, amarse ${ }^{10}$.

En el grupo de dos el partner es también el más próximo: se puede ver en él el obstáculo, el competidor más o menos valioso que uno, el elemento extraño y hostil al yo; pero se le puede ver también, a él o a un tercero junto a él, como camarada, colaborador, incluso como quien nos libera de la soledad. Se advierten entonces no sólo las diferencias, sino también y especialmente las similitudes e igualdades: ¡es un hombre como yo!; sus deseos, esperanzas, temores, son como los míos; sus metas, dones y carencias, emparentados conmigo. Quiero extenderle mi mano de manera que atravesemos juntos los riesgos de la existencia.

Nos hallamos aquí ante las dos antítesis de toda relación entrehumana: el pro recíproco y el contra recíproco $(Z u / G e g e n-e i n a n d e r)$. Los grupos a dos pueden mostrarse proclives a la unión pero también a la separación. Ambas tendencias se mezclan de modo muy vario: los miembros del par lo mismo pueden estimularse y completarse que enfrentarse, obstaculizarse y, en todo caso, limitarse. Este esquema básico tiene, sin embargo, su articulación. En el pro se puede tratar de la mera utilidad individual: se estima la capacidad del compañero y se tiene claro que la duplicación del trabajo es más que la simple adición 1 más 1 . Pues bien: ya esta fría consideración utilitarista trae consigo el que haya que tener en cuenta al otro, atender a sus intereses y garantizarle su libertad de acción. El grado de éxito de semejante atención dependerá de las relaciones de poder de ambos. Por lo regular, uno está más obligado al otro. Semejante desigualdad de poder acarrea la posibilidad de utilización y hasta de explotación; y así el pro ( $z u$ ) inicial contiene gérmenes de contra (aus-). Y si la sobrecarga del partner más débil, que no puede liberarse, se acentúa, el explotador corre peligro de debilitarle, y la atenuación de esa capacidad repercute desfavorablemente sobre su propia situación de más fuerte.

La simpatía, constituida a partir de una unión más estrecha entre los partners, crea un vínculo también más fuerte en la relación a dos. La simple costumbre de trabajar juntos con eficiencia similar trae consigo las más de las veces una aproximación emocional. Sobre todo si el pequeño grupo se enfrenta a un entorno indiferente o adverso, nuestros dos hombres se unirán en estrecha camaradería. La lucha por existir les une.

Junto a la pareja amorosa, el matrimonio y la familia, la consanguinidad y la consexualidad constituyen un tercer elemento positivo. La familia es el principal tipo de anclaje firme de los pequeños grupos. De ahí que el estallido de la

10 Para lo que sigue, cfr. también el cap. IV ( $V$ Vom Schickschale des weiblichen Geschlechts») de mis Spätlese, Köln und Opladen, 1954, pp. 55 ss. 
misma por la oposición de caracteres sea tanto más destructivo. El matrimonio puede convertirse en áspera antipareja; la oposición de las generaciones puede trocarse en conflicto atormentador y destructivo entre padre e hijo, madre e hija; los hermanos pueden enfrentarse hasta el aborrecimiento. En cualquier tipo de vinculación basado en la simpatía, vaya de amigos o camaradas, existe, tras algún tiempo, el peligro del extrañamiento y aun de la hostilidad, esto es: el tránsito, también aquí, al anti-par, una de las tendencias más dolorosas y dañinas. Tanto más firme y fecundo es el mantenimiento de la lealtad, siempre que sea sincera y voluntaria.

A estas fuerzas del pro y del contra, enraizadas tanto en el ámbito individual/psicológico como en la organización social racional, se les suma la bendición moral y religiosa que suele dispensarse a los pequeños grupos. La idea de caritas (en su sentido más amplio) apunta sobre todo al prójimo. El amor al prójimo constituye el eslabón más firme de esta vinculación. Es verdad que, en el evangelio, a la pregunta ¿quién es mi prójimo? se responde: aquel que padece necesidad, por muy ajeno que nos pueda ser. Pero, más allá del auxilio al lejano, no hay que olvidar la solicitud por quienes pertenecen al propio grupo; es en el transcurso de la vida cotidiana, en las relaciones de pareja y en el pequeño grupo, donde encuentra su campo de acción, propiamente, el deber del amor al prójimo.

Pero es dudoso que allí donde falten los intereses egoístas y la simpatía libremente dispensada baste, para afianzar de forma efectiva los pequeños grupos, el anclaje de lo social en el deber ético-religioso. Afirmar, sin embargo, que en éste se trata de algo simulado, sería suponer un cinismo inhumano, cuando en realidad es pura fórmula.

Vayamos al antipar ${ }^{11}$. Estaríamos aquí ante grupos de a dos unidos, interna o externamente, por la fuerza, aunque ambos quisieran separarse. Sobre esto tengo escrito: "las relaciones de confrontación tienen amplio espacio en el habérselas de la pareja. Sobre todo en circunstancias de la vida duras; es entonces, p. ej. ante preocupaciones económicas, cuando se amontonan los roces de aquélla. Quienes se sienten socialmente oprimidos, impotentes, enojados y frustrados derivan hacia su compañero de pareja toda la rabia que no han podido satisfacer en la lucha general por la vida. No entendiendo, debido a sus cortedades, suficientemente las relaciones de la vida social, buscan algún culpable y creen encontrarlo en su compañero (partner). Precisamente porque la intimidad de tal grupo apenas experimenta trastornos exteriores pueden, entre las cuatro paredes, volcar sobre el compañero el peso de su tortura, el desengaño de su ambición o de su terrible vanidad; pueden escarnecerle o atormentarle, amontonar sobre él culpabilizacione; pero tan mezquino comportamiento les hace aún más miserables; a menudo después, cuando no demasiado tarde,

${ }^{11}$ Cfr. para esto, así como para la teoría general del par, del trío y de los otros grupos pequeños, el 3. ${ }^{\text {er }}$ capítulo de la 3. ${ }^{a}$ parte de mi System der Allgemeinen Soziologie, 3.a ed., Berlín, 1955, pp. 447 ss. 
sienten remordimientos» ${ }^{12}$. Podríamos distinguir también aquí distintos tipos y grados de confrontación. Así, en el compañerismo profesional o de los negocios, personas indiferentes, e incluso desagradables entre sí, pueden a veces unirse por el común interés. El fin objetivo y la ventaja de su unión puede ser tan fuerte para ambos que apenas les estorbe la falta de comunión interior. Hasta puede ocurrir, una vez más por la costumbre misma, que la antipatía disminuya hasta el punto de que progresivamente vayan prevaleciendo los rasgos positivos de la comunidad.

Allí donde, como en la vida familiar, las amistades o grupos de confianza (Vertrauensgemeinschaften), la vinculación afectuosa sería precisamente la base, la confrontación latente de los partners llega a crear una atmósfera de insinceridad que, aun cuando escondida largo tiempo, puede irrumpir con fuerza aniquiladora en un instante de enajenación, destruyendo, duraderamente o con difícil remedio, la cohesión del grupo.

Con el grupo a tres (Dreiergruppe) nos enfrentamos a la mística del número trino; número que nos sale al paso no sólo en el ámbito religioso de la doctrina de la divina trinidad (Padre, Hijo y Espíritu Santo), sino, muy especialmente, donde el tercer elemento es un producto de la unión de otros dos (padre, madre, niño): es aquí donde tiene una misteriosa fuerza. Por doquier se nos muestra como algo esencial: políticamente, en la división tripartita de los poderes (legislativo, judicial, ejecutivo), de Montesquieu; filosófica e históricamente, en la dialéctica de tesis, antítesis y síntesis. Los triunviratos fueron frecuentes en diferentes etapas de la historia de los estados, en base a la experiencia de que el tercer elemento podía frenar a los otros dos a la hora de formar pareja y su resultante predominio; también es posible formar mayoría de dos contra uno.

Es en la vida social, privada o pública, donde se pone de manifiesto el hecho muy frecuente de que la entrada de un tercero cambia la relación a dos, debilitándole o fortaleciéndole. Lo vemos a diario: niño recién nacido y padres; suegra y pareja; amigo de casa y familia; dos amigos y novia o amigas y prometido; padres mayores e hijo criado; huéspedes, empleados del hogar, etc. Con frecuencia, en estos casos va de dos contra uno. Cada uno de los partners reacciona de forma distinta ante la aparición del tercero; dígase otro tanto de éste respecto de uno y otro. A veces destruye la armonía, a veces la fortalece justo cuando la pareja cansada amenazaba disolución ${ }^{13}$. A partir del grupo a tres puede constituirse un doble par cuando el tercero venido a menos busca sustituto y fuerza fuera del grupo vigente.

No puedo demorarme mucho en los pares y los tríos. Lo dicho aquí se puede completar ampliamente con lo escrito en mi Sistema de Sociología. Ahora se trata para mí menos de una contribución al conocimiento de las relaciones de intimidad que de la introducción a la exposición sobre los grupos

12 O. c., p. 472.

13 Cfr. System, p. 437: Die Dreiergruppe; en particular, parágrafo 14: la pareja y el tercero. 
mayores; mucho de lo que caracteriza a éstos pero que resulta difícil de analizar podemos observarlo con mayor claridad ya en los grupos muy pequeños. Primero, porque en éstos se ven tanto mejor las implicaciones del con- y del contra, la polaridad de atracción y repulsión, cuanto que constituye la fuerza determinante en el conjunto de la vida entrehumana. Segundo, porque también aquí se reconoce la esencia de la vida propiamente social, que luego, en la forma de imágenes/constructos de la sociedad, se hace más opaca para la investigación. Cuanto más el observador de la diada tenga ante sí, una y otra vez, la especificidad anímica y la totalidad de la persona que el psicólogo estudia, tanto menos servirá la mera psicología individual para llegar a la comprensión del pequeño grupo, ni tampoco del par. Aun cuando el par sea lo más personal que hay en todos los constructos sociales y sea en él donde se produce la acción del individuo sobre el individuo, vale la pena advertir que la diada actúa siempre de modo distinto a como cada uno de sus miembros en particular, o al menos el más pasivo de ambos, habría actuado. El personal influjo (hacia el exterior) de cada uno en particular sobre un tercero suele acentuarse desde la relación a dos; pero, a su vez, aquél queda transformado, disminuido, debilitado, por el mismo hecho de que la interacción sea con un otro. A menudo las decisiones y tomas de posición de A respecto de un tercero se deben menos a su actitud íntima originaria que a las preferencias o aversiones del partner B. El influjo de Eva sobre Adán es todo un símbolo. Pero no se trata en absoluto del mero influjo de la mujer o de la amada sobre el varón, como si la solución del misterio viniera dada por el cherchez la femme y el desplazamiento de todo el problema a la esfera de lo sexual; en muchas ocasiones la erótica puede de hecho ser una explicación suficiente de la conducta; pero con mayor frecuencia es del conjunto de esta relación de par como tal (acaso totalmente asexual) de donde emana el hecho de tratarse o el de abandonarse ${ }^{14}$.

Las actuaciones de A sobre B y de B sobre A crean una relación a dos en la que se mezclan de forma peculiar las manifestaciones personales de cada uno, pero casi nunca a partes iguales; el partner más activo determina las más de las veces las actuaciones y las dejaciones del par; depende en buena parte de los aspectos de la vida misma: quien en uno es más activo puede ser más pasivo en otro. Con frecuencia, tales influjos son desconocidos de entrada por ambos, habida cuenta de que, con la creciente intimidad, se aprende pronto a mirar el mundo también con la mirada del otro; a menos que la estupidez o el orgullo dificulten la entrega al compañero. Tales actuaciones pueden fortalecer o debilitar el sentimiento del yo; pueden elevar o humillar; destruir y aniquilar. En mis lecciones sobre los grupos pequeños traigo a veces a colación un triste suceso de la historia criminal de Colonia: una pareja de jóvenes estudiantes había disparado a un cobrador y su casera; lo digo expresamente: la pareja como tal había matado a su víctima. Los disparos incluso, según supe, habían sido hechos por el varón; pero en una conversación previa habían concebido

${ }^{14}$ Cfr. o. c., p. 470. 
los dos el plan y se habían persuadido recíprocamente para llevar a cabo el asesinato. Conocía a la joven por mi seminario. Lo que menos podía pensar yo es que hubiera sido capaz de cometer un asesinato por robo de ese modo. De hecho, se podría afirmar: ella sola no hubiera osado dar semejante paso. Y el caso es que su marido daba, durante el proceso, la misma impresión. Pero su recíproco influjo les llevó a los dos a ahogar progresivamente los escrúpulos que podrían tener. Como si se dijeran: puesto que tú lo piensas, es posible hacerlo. Se descargaba así cada uno de su responsabilidad, distanciándose, poco a poco o de repente, del propio yo. Eso fue lo fatal. Igual que a la depravación, también la dependencia a dos puede llevarnos a acciones nobles que jamás habríamos hecho por separado. En dos palabras: la vinculación a dos crea una nueva base de comportamiento: muestra, es verdad, los elementos de A y de B, y hay que analizarla psíquico/individualmente, pero el todo (en este caso la conducta de la pareja) no es igual a la suma de las partes (esto es: a la invidualidad de A y de B ): contiene también influjos sociales, fuerzas derivadas de la unión de A con B. No vale decir: el todo es más que la suma de sus partes, si por «más» se quiere significar un grado superior de valor; puede ser, en efecto, que el rendimiento de un trabajo compartido sea superior, y el resultado, cuando interactúan, más grande de lo que hubiera sido la suma de las actuaciones por separado de A y de B. Pero no siempre es ése el caso, ni muchísimo menos. Prescindiendo de la valoración ética que pueda darse a la palabra "más», la actuación conjunta puede también disminuir las capacidades psíquicas o espirituales. Si el más capaz depende de la estulticia del más débil, la acción conjunta estará por debajo del nivel que hubiera alcanzado por separado el más hábil.

Si me demoro en la consideración del par es porque, como dije, es en los grupos pequeños donde mejor trasparece la esencia propia de lo social y, con ella, la de los constructos entrehumanos de todo tipo, hasta la de los colectivos más abstractos. Se reprocha en ocasiones a los psicólogos que no tengan ningún órgano para la comprensión de lo social, y que conviertan la sociología en psicología social. Pero no es posible reducir ni los constructos ni las relaciones sociales, simplemente, a la idiosincrasia de los que en ellos participan; pues actúan bajo la presión de coerciones sociales, no de su mera libertad personal. Cuando se trata de las grandes corporaciones (pueblo, estado, iglesia, comunidad cultural), la coerción no procede sólo de individuos particulares concretos, sino que son fuerzas ideales y suprapersonales las que imponen a los hombres comportamientos que les llevarán muy lejos de sus impulsos e inclinaciones ${ }^{15}$.

15 Esta relación entre sociología y psicología ha sido elaborada, entre otros, por Theodor Adorno en su ya mencionada contribución a la obra colectiva Soziologica, Frankfurt a.M., 1955. Cito de ella: "que las tendencias sociales se abren camino sobre las cabezas de los hombres (se imponen a los hombres), que éstos no las reconocen como propias, es lo que constituye el velo social. Sobre todo aquellos cuyo trabajo les mantiene con vida, a sí y al conjunto, cuya vida no obstante depende confusamente del todo, no pueden reconocer que la sociedad es tanto su quintaesencia como su contrario» (p. 20). 
Es verdad que, con la creciente cosificación — que va desde el par, a través de los grandes grupos, hasta las corporaciones-, se manifiesta, con más fuerza cada vez, el poder determinante de lo social en la vida, a costa de lo personal. Sólo que hay que precaverse de caer en la representación mística de la sociedad como un constructo universal todopoderoso. Tendré ocasión de repetir en lo que sigue que no existe en absoluto semejante universo. Pero la antiquísima, primigenia y creciente interdependencia de los hombres (de tipo positivo o negativo) ha creado un reino de ideas con poder sobre las cabezas y los corazones humanos, en lucha con las fuerzas individuales de la vida y del alma. El pensamiento abstractivo del investigador es capaz de separar este reino de representaciones y presentimientos del de las almas individuales, y de concebirlo como un quantum (Grösse) autónomo: lo social, precisamente; pero con el riesgo de cometer la falta inversa a los psicólogos, esto es: aislar en exceso lo social y verlo como lo que domina sobre todo. En las vivencias, lo psíquico y lo social están estrechamente unidos.

Este algo difícilmente abarcable que llamamos lo social es más fácil de captar si, como hicimos arriba, mostramos, ya en el par, su penetración en el círculo del yo. No es en los grupos mayores, las corporaciones o la masa donde primero aparece: está ya en la vinculación de $\boldsymbol{u n}$ yo con $\boldsymbol{u} \boldsymbol{n}$ tú.

\section{Los grupos mayores y los grandes grupos}

Estamos ya preparados para aplicarnos al estudio de los grupos mayores, bien entendido que, como hasta ahora, no adopto la expresión "grupo" para cualquier tipo de constructo social; en el sentido estricto que vengo utilizando representa más bien un tipo. Distingo grupo de círculo, de masa, de corporación. A diferencia de la masa, el grupo muestra una duración y organización, esto es: reparto de tareas relativas entre sus miembros. En la masa, la socialización llega hasta donde y mientras prevalecen los instintos y deseos de los hombres particulares; el grupo, en cambio, se sobrepone con su organización a las cambiantes exteriorizaciones de las individualidades; lo social trae en jaque en mayor grado lo anímico/individual. Hay que diferenciar también entre los grupos organizados y los círculos: vinculaciones entrehumanas, latentes, pero que se manifiestan en determinadas situaciones; dígase, p. ej., la gente sencilla, el proletariado, la buena sociedad, el público; en realidad, nunca están organizadas pero pueden constituir la base para organizaciones diversas. Las corporaciones, en fin, son socializaciones de máxima potencia. Las tenemos impersonalmente por portadoras de valores duraderos no uncidos al transcurso del plazo vital de los hombres en particular; estados e iglesias, esto es, colectivos de la vida política y religiosa, representan las corporaciones más importantes.

Pero nuestra atención se dirige por lo pronto a los grupos grandes y mayores diferentes de los pequeños grupos de a dos y de a tres estudiados ya. Los pares (diadas) y los tríos (triadas) se distinguen de los grupos que constan de 
más de tres o de cuatro en que, por su misma pequeñez, se configuran de manera más personalizada que los grupos grandes, más cosificadores (die sachlicher wirken). La fuerza específica, extrapsíquica, que llamamos lo social se hace valer en ellos frente a lo anímico en mayor medida (justo gracias a la organización). El principio del orden encadena el capricho de los hombres. Esto que, como vimos, se apuntaba ya en el par, se acentúa más y más. En los círculos y masas no es tan manifiesto; lo que en éstos hay de anímico es más de origen colectivo; lo que prevalece no son las diferencias individuales del instinto o del sentimiento, sino lo comunitario de la vida instintiva, lo que tiene de horda. Por eso se ocupa de su estudio la psicología y, dentro de ella, la psicología social.

Lo que conviene considerar en los grupos mayores y grandes, que abreviadamente llamo grupos $B$, es que (en mucha mayor medida que en el par medio) su conducta, con relación a la de los hombres particulares por separado, es diferente. Hablar aquí de conducta de grupos no deja de ser una expresión abreviada. Los constructos sociales como tales no pueden, en absoluto, "comportarse", pues no son sino conglomerados de procesos sociales, y éstos (los procesos, los sucesos), no las personas, son sus elementos. "Conducirse» lo hacen los hombres de carne y hueso, no los constructos representados idealmente. Los constructos son construcciones (Gebilde sind Bilder) ${ }^{16}$. Así, el

16 Nota del traductor: Gebilde ha sido traducido, al hilo de su empleo por autores afines, más frecuentemente mediante la palabra "configuración». Pero los distintos términos han de ser diferenciados con la máxima nitidez posible, si queremos evitar comprensiones defectuosas; pensamos que ha de traducirse — al menos desde Wiese- con el término castellano de "constructo", ya que éste cubre simultáneamente dos aspectos de nuestra tarea: contiene una mayor literalidad en su acepción y refleja esa "vacuidad semántica» que Wiese — desde consideraciones metodológicas - exige en un primer momento al concepto sociológico como tal, motivo, además, por el cual explícitamente dice escoger este término alemán frente a otros. En ocasiones muy puntuales, puede también traducirse incluso como «imaginario», cuando Wiese se refiere enfáticamente a su "función ideal, idealizadora o ideologizante» que las Formungen — Wiese suele recurrir también al término alemán Formung («formación»)— adquieren cuando penetran las relaciones sociales: al reconstituirse en «representaciones ideales» o «imágenes»; su traducción por "formatos», "cuadros» o «marcos», podría ser otra opción válida, cuando por influencia simmeliana Wiese remite metafóricamente a ellas en tanto que «imágenes plásticas». La misma posibilidad de atribuir al término varias traducciones confirmaría el logro de aquella vacuidad pretendida desde Wiese para la propia terminología sociológica, donde la polivalencia semántica que queda subsumida en el concepto sería ya el resultado mismo de las concepciones «no científico-sociológicas» que se van realizando, a medida que van forjándose relaciones humanas, en el sentido más amplio. Es la reiteración de tal acontecer la que asienta definitivamente determinadas "esferas de lo humano", que en su circularidad se nos presentan no sólo como cosmovisiones, sino como "cosmorrealizaciones» de lo, ahora ya, inter-humano. Desde las que, a su vez, cada particular se ve abocado a reactuar ya con ese «entre» formalizable, reelaborando algún tipo de "formación» social que, de entrada, le "con-formaba». Y ello a modo de "resultado personal» de confluencias situacionales redefinibles; de emergencia abstracta desde aquella vasta y firme red de "cosmorrelaciones» que presituaba al individuo en un espacio dinámico pero preciso y le colocaba a una distancia concretable de otros hombres. Bilder queda traducido, pensando en esta lógica discursiva wiesiana, como "construcciones». 
"comportamiento de los grupos" sólo puede significar comportamiento de hombres asignados o asignables a un grupo. Lo decisivo aquí es la representación de que «se pertenece» a un grupo, es decir: se está dominado por la idea de un determinado tipo de vinculación con otros hombres; puede llegarse incluso a la ficción de un "espíritu de grupo" (Gruppengeistes) unitario poseedor de una cierta existencia propia en un mundo inmaterial.

Ahora bien: resulta insostenible la consideración del hombre particular como «parte» de un grupo, aunque sólo sea porque «pertenece» las más de las veces a muchos, a muchísimos grupos. Jamás un hombre es asumido en su totalidad, con todas sus capacidades espirituales, por ningún grupo; puede, en cambio, pertenecer, por instantes, totalmente a una masa. Y, sin embargo, el influjo de una cierta dependencia de grupo sobre su pensamiento y su sentir puede ser tan fuerte que le domine coactivamente perdiendo toda vergüenza y autocontrol (como en la masa, por lo demás). El deseo de entrega al grupo sustituye a la conciencia inquisitiva y crítica. No es tan raro que bajo su presión el hombre se haga muy primitivo moralmente. En tal estado no reconoce más virtud que la obediencia al grupo que le procura modelos, imperativos y escalas. Se impone la tendencia a la subordinación. Es verdad que son las grandes corporaciones las que, en definitiva, imponen la obediencia, pero lo hacen a través de los grupos, más próximos a (aunque a la vez lejos de) las personas particulares: asociaciones, ligas, cliques, tertulias (Stammtische), círculos, sindicatos; son tales grupos los que, de entrada, median la dependencia de los individuos con las grandes corporaciones ${ }^{17}$. La multitud de grupos es inabarcable. Existen infinitas asociaciones políticas, clubes deportivos, cliques, células, organizaciones económicas, grupos literarios, agrupaciones científicas. Para ordenarlas habría que empezar distinguiendo entre grupos de libre opción (Wahlgruppen) y grupos por obligación (Zwangsgruppen) ${ }^{18}$, por más que a veces se imbriquen. Son las corporaciones las que suscitan los grupos forzados, p. ej. en las secciones del ejército o en las clases de las escuelas. La pertenencia voluntaria a los grupos depende de la decisión, efectiva o aparentemente, libre

${ }_{17}$ Cfr. System, p. 488.

18 Nota del traductor: Detrás de esta diferenciación está el concepto sociológico de Tönnies de Willkür, que caracterizaría a los específicos procesos de formación («formas de voluntad» en Tönnies) de la Gesellschaft. Sin embargo, p. ej., frente a la inversión de la lógica explicativa que realiza Mannheim - y que queda cifrada en su término alternativo de Kürwille, con el que pretende enfatizar el carácter primigenio de «lo arbitrario» frente a "lo voluntario»-, Wiese trata de poner el énfasis en la "presión situacional» como definitoria del carácter diferencial de la Gesellschaft. De ahí que traducimos el concepto de Wahlgruppe por grupo de libre opción (más literalmente: "grupo de elección»), en el sentido de que el individuo "dispone de la opción» de aceptar o rechazar las características de un grupo, y en el límite hasta de seguir perteneciendo a él por "voluntad autónoma o libérrima", sin sentirse sometido por ello a presión alguna; y Zwangsgruppe, por grupos por obligación, poniendo el énfasis en la situación del individuo: éste «se encuentra ante, frente o con la obligación» de asumir aquellas características por el mismo hecho de que no puede evitar hacerse, de algún modo, partícipe de la voluntad mayoritaria del grupo, so pena de ser castigado o expulsado de su entorno vital. 
de las personas. Pues el concepto de decisión libre es equívoco. Puede no darse un forzamiento propiamente tal; pero la tradición, el «qué dirán», la seducción retórica, las exigencias y convenciones profesionales, las relaciones familiares... pueden ejercer tal influencia sobre el yo, aunque en parte se resista, que convierten la opción pretendidamente libre en pura ilusión. Pero en la medida en que efectivamente se propugne la adscripción a, o la permanencia en, un grupo hay dos fuerzas anímicas sobre las que se debe llamar la atención si se quiere entender lo social: son los deseos y los temores del hombre, que imprimen su huella en gran medida a todas las ideas, convicciones y decisiones en la vida cotidiana.

Es en la fe donde mejor se pone esto de manifiesto. La fe prescinde por completo de la percepción, que es la que, por lo demás, constituye el camino adecuado para nuestro conocimiento. Se dice en el evangelio: «si no veis signos y maravillas no creéis». Pero el número de hombres que hacen depender su fe de sus sentidos es exiguo. Más general es la convicción: creo puesto que no veo. Actitud que puede llevarse al extremo, por no pocos compartido, de Tertuliano: "creo porque es absurdo». La fe, como también muchos juicios y opiniones, no enraiza en la percepción, sino, precisamente, en deseos y miedos. Su influencia alcanza a los sistemas más abstractos de la filosofía y está en lucha constante con las constataciones objetivas del conocimiento que querría liberarse de su dominación. Y cuando miedos y deseos son arrojados del ámbito del pensamiento se refugian en los rincones más desapercibidos del espíritu.

En el caso de los "grupos de libre opción» lo decisivo es que constantemente acecha la exigencia a la par que el temor de que, a través de la mera vida entrehumana, éstos no logren cobrar realidad. Podemos resumir los deseos en cuatro grupos $^{19}$. Muchos han colaborado en la configuración de esta teoría; yo mismo $^{20}$ : la exigencia de seguridad, de correspondencia, de reconocimiento y de nuevas experiencias. A estas tendencias hacia la socialización corresponden las angustias de: quedarse solo y abandonado sin adscripción a grupos; no encontrar quien simpatice con nosotros; o en tercero y cuarto lugar, que no se nos reconozca y valore, caer en el aburrimiento.

Es verdad que el propio grupo (es decir: los otros hombres unidos en él) exige del miembro voluntario (Willigen) situarse en un orden y obediencia al mismo. Succiona de esta voluntariedad (Willigkeit) de las personas lo que contiene de conciencia de sí mismo junto con ese egoísmo, a menudo tan sorprendentemente intenso. Por regla general, el egoísmo de grupo es fuerte y acusado hasta donde el restante mundo social lo consiente. Desvergonzado hasta donde es posible, se tiene por el ombligo del universo; como dijimos, saca su fuerza de la voluntad de subordinación de sus miembros. El grupo reclama de tales hombres el cumplimiento del deber hacia él; libera a sus miembros de la ver-

19 W. J. Thomas es el primero que lo ha hecho en su Polish Peasant in Europe and America y en Unadjusted Girl (1923).

${ }^{20}$ O. c., pp. 167 ss., 255 ss.; sobre todo, en relación con la teoría de los grupos, pp. 493 ss. 
güenza y de su tendencia a crearse remordimientos puesto que, como yo intenté expresarlo: «el miembro individual podría decirse: lo que hago no lo hago inmediatamente para mí, sino para mi círculo social; así, le sirvo. En la vida personal la conciencia del hombre exige una conducta que, más o menos, responde al "ama a tu prójimo como a ti mismo". Tu prójimo es no obstante cualquiera que padezca necesidad. En la vida de grupo el ideal es: ama a tu grupo más que a ti mismo; odia cuanto se le oponga; más aún: odia a todo lo que no le sea afín» ${ }^{21}$.

La fuerza que le lleva al logro de semejante validez la toma el grupo de aquello que constituye su característica propiamente sociológica: «el criterio de orientación» o la regla (Richtmass) ${ }^{22}$. Si, como dijimos, necesita de la organización para anunciarse como un especial variante de constructo, su constitución interior y el influjo sobre sus miembros se explica principalmente porque actúa mediante el símbolo de un modelo (Vorbild). Con mayor o menor claridad exige que sus miembros se formen según esta regla; ella es la objetivación total o parcial de la meta del grupo. En ocasiones, esta regla lo es a modo de una persona, viva o muerta, conocida por los miembros del grupo; en ocasiones, a modo de una visión de futuro a la que se aspira; a veces se objetiva en la forma de cosas elevadas a símbolo: bandera, cruz, emblema. Si se quiere entender a un grupo hay que esforzarse por entender, en cualquier caso, su regla.

Caracterizar al grupo por su egoísmo y su capacidad de vencer el sentimiento de vergüenza de los individuos conscientes de su inseguridad, no significa que la vida de grupo rebaje moralmente siempre a la persona. Al margen de su egoísmo colectivo, aquélla apunta además hacia otro peligro: la tendencia contra todo lo que supere a la media (Überdurchschnittlichen). Es ya una suerte si la actitud grupal se atiene a la de una media penosa; especialmente cuando se da un gran número de miembros tiende a hacer concesiones a lo que está por encima de la media (Unterdurchschnittlichen). Donde sobre todo falla es en cuestiones de gusto, de capacidad para distinguir el bien del mal, de diferenciación de las impresiones; a no ser que la regla se establezca a un nivel de mesura tan elevado que incluso los elementos más valiosos puedan sentirse acomodados en el grupo. Pero a menudo los miembros más sensibles de la organización sienten repulsión por la grosería de juicio y de trato que domina en el gremio; el nivel les resulta harto ordinario. El cuadro es diferente si se

21 O. c., p. 488.

22 Nota del traductor: El término Richtmass(e) es sinónimo de Eichmass(e), por lo que puede ser entendido como "medida de la regla», "medida legal», "medida que guía» con mayor precisión. Y ello porque, además, como en numerosas ocasiones Wiese hace confluir la etimología del término con el contenido sociológico pretendido, intenta dejar a sus términos "la posibilidad abierta» de convertirse en "categorías sociológicas de medición», que puedan ajustarse, a su vez, a su pretensión simultánea de encontrar un último criterio ético correlativo: la mesura. Lo traducimos aquí por «la regla», recogiendo metafóricamente las connotaciones "matemático-geométricas» y "jurídico-normativas» que puede contener en distintos contextos; en el preciso sentido de que la regla "marca los criterios mensurables para juzgar con mesura», y por lo tanto el "Criterio» para juzgar a los miembros de un grupo y para orientarse en el mismo simultáneamente. 
mira desde el punto de vista de los que están por debajo de la media y de los que precisamente se ajustan todavía a esa media. Hombres que van tirando sin adscripción a grupos, y que reducidos a sí mismos apenas serían eficientes, empiezan a recibir del grupo que les admite metas, energía y buena voluntad. El ejemplo de los juiciosos y la fuerza de la regla les hace caer en la cuenta, por vez primera, de que también ellos son capaces de hacer algo y que podrían ser factores útiles, que podrían poseer una autoconciencia merecida.

Aquí reside lo propiamente social: en su capacidad de transformar a las personas en buen o mal sentido. Partiendo del par para llegar hasta las corporaciones, y con particular claridad en los grupos $\mathrm{B}$, se podría distinguir entre un yo personal y un yo social. Con el primero me refiero al núcleo esencial (Wesenskern) del Homo, invariable al destino y a cualesquiera influjos de las circunstancias; la específica singularidad de la persona que no está determinada por los otros, indefinible e inderivable pese a los constantes y fuertes influjos de los demás y de los constructos sociales. Sólo cuando amamos a otro hombre penetra nuestra mirada hasta este yo oculto; en la cotidianidad del trato habitual no nos apercibimos ni en nosotros ni en los demás de este yo personal, sino más bien de ese producto-entorno (Umweltprodukt): el yo social cuya conducta depende de la situación. De él escribí: «se configura según las exigencias sociales, está expuesto a la coacción de la sociedad, sucumbe al influjo de los modelos, se sirve de máscaras, se anquilosa en tipos (erstarrt zum Typus), es independiente de relaciones categóricas: es un producto del entorno. Pero, a mi entender, el hombre muestra siempre como una coloración de la conducta que no está determinada por los otros. En el hombre social puede pasar desapercibida; pero en personalidades fuertes y singulares puede irrumpir en determinados momentos poderosa y acaso supraterrestre ${ }^{23}$. Al hablar (abreviando) de egoísmo de grupo, metas de grupo, etc., debe recordarse una vez más que semejantes constructos no descansan sino sobre una hipostatización, es decir: sobre cosificaciones; recordamos que nos encontramos ante acontecimientos, no ante sustancias ni suprapersonas con metas y autonomía. Son siempre los hombres «adscritos» a los constructos los que sienten y piensan así; pero en los embrollados procesos de mutuo acomodo surge una relativa similitud en las reacciones que se nos aparece con una característica de totalidad a la que llamamos grupo. Si uno o pocos particulares se enfrentan a su grupo se oponen efectivamente a la mayoría de los miembros o a los representantes de esa mayoría que se equivaldría en mayor o en menor medida a la esencia del grupo. Cuando analizamos supuestas características o comportamientos del grupo, éstos acaban siempre disolviéndose en procesos anímicos o anímico/corporales de los hombres. Lo social no es ninguna fuerza mística o suprapersonal; siempre es reducible a la peculiaridad de hombres presentes o pasados, pero que, repito, no pueden explicarse con la psicología profunda a partir sólo de la naturaleza individual, sino partiendo

23 O. c., p. 142. 
de una peculiar dimensión del alma: lo social. Lo que aquí acontece tiene sus reglas propias. Sólo ciertas fuerzas anímicas son aptas para someterse a esta transferencia (Übertragung); el yo personal permanece intacto. Nadie puede agotarse nunca en cada uno de sus grupos; éstos no asumen sino lo que resulta adecuado para ser luego transmutado sobre otros (hinüberwechseln). Tan justo como afirmar que la habitual consideración de la psicología individual no basta para esclarecer al grupo, lo es decir que el sociologismo se reduce a mística indemostrable cuando atribuye a los constructos una fuerza sui generis que trasciende lo anímico.

Hay que destacar, por otra parte, que si, p. ej., queremos explicarnos una conjura de diez personas simplemente mediante el análisis, en una tras otra, de la peculiaridad de cada una de ellas, no lo lograremos; porque para la conclusión, a la que llegan, de cometer el atentado es decisivo saber la influencia mayor de alguno de los diez, quién pudo acallar ciertos miedos, cómo se creó la situación... y muchas otras cosas que dependen del entorno, del momento y de la regla que señorea en el grupo. Todo esto y mucho más constituye lo social. La capacidad o el riesgo del singular de dejarse influir o dirigir, en la conciencia o en la conducta, por el grupo varía según los casos. De ello diremos algo más en un capítulo posterior dedicado a la consideración del ámbito público y del privado.

\section{La masa}

Vayamos ahora del grupo a la masa. De ella se podría decir mucho, sobre todo bajo el punto de vista sociopsicológico. Para una investigación más compleja de este constructo debo remitirme, sin embargo, a mi Sistema ${ }^{24}$. En otro tiempo distinguí, dentro del concepto "masa», entre masa concreta y masa abstracta. Pero ahora he eliminado esta distinción llamando a la masa abstracta círculo, tratándola aparte. De ella diré algo todavía más abajo. Tratándose de la masa concreta, «masa» a secas digo ahora, hay que evitar confundirla con la «multitud» (Menge): ésta ni siquiera remite a un concepto sociológico, pues no significa ningún proceso de relación entrehumano; pero tan pronto como dentro de la multitud actúan (einwirken) hombres sobre hombres, tenemos la masa. Lejos de estar organizada como el grupo, en sus estados iniciales, carece de guía. Y sólo cuando un líder crea orden y reparte funciones se aproxima la variante masa al concepto de grupo. Pero se diferencia de él en que no pasa de ser resultado de un instante; no posee duración mayor alguna. Lo que conecta a los hombres amontonados en forma de masa son los afectos, inflamadas pasiones e instintos. Lo que hasta entonces se mantenía más o menos contenido y oculto irrumpe, dada la situación adecuada, como una conducta inmeditada. Instantáneamente y con gran rapidez entra en juego la imitación. Los

${ }^{24}$ Cfr. o. c., pp. 407 ss. 
vacilantes son arrastrados por los impetuosos al frente. Semejante rápido comportamiento es posible sólo porque, en mayor o menor grado, se han ido acumulando en las almas de todos los participantes sentimientos similares hasta entonces represados.

Pero no podemos investigar más el aspecto psicológico. Lo que aquí nos concierne es la cuestión de cómo se anuncia lo social en el comportamiento de las masas emparejado con otros factores psíquico-individuales: la autoenajenación de la persona, el dominio de lo "extra-yo" (Ausserich) sobre lo interior, la elevación de la voluntad individual hasta convertirse en energía colectiva que desborda la mera suma de las capacidades individuales; y, sobre todo, la resolución de lo latente y semiconsciente en forma de un acto unitario, ante el cual uno tiene la impresión de que ya no son los individuos vacilantes, sino una fuerza de choque (Stosskraft) unitaria e indiferenciada la que actúa. La masa nos produce la impresión de algo demoníaco, tanto más impersonal cuanto que las pasiones alcanzan en los participantes un grado de inflamación que jamás muestran ni antes ni después en la vida cotidiana, en absoluto; y ello lo mismo si aquélla se forja para llevar a cabo conductas nobles, desinteresadas, tal que una cruzada o la liberación de presos (asalto a la Bastilla), como si se reúne bajo el afán de destrucción. Actúan como posesos. Junto a semejantes arrebatados no faltan tampoco las más de las veces elementos más pasivos que «colaboran»: en parte por la presión de los otros, en parte por curiosidad, en parte por instintos que, sin embargo, no tendrían fuerza suficiente para adueñarse de su conducta si tales personas no se esforzaran en imitar a los más impulsivos.

Por mucho que ambas fuerzas se imbriquen, hay que separar de nuevo hasta donde sea posible lo social de lo anímico-individual. Pero en esta ocasión lo cósico no se manifiesta nítidamente a modo de algo cósico junto a lo personal, sino que actúa como una fuerza impulsora en la psyche. En experiencias anteriores con otros hombres (p. ej., en la relación ricos/pobres), en el común destino, en desengaños y resentimientos, en las relaciones con los empresarios, los vecinos, la familia, etc.: ahí residen los auténticos motores para los sentimientos previos a la conducta y para el acto suscitado por la situación.

\section{Los círculos y la atmósfera social}

Las consideraciones sobre la masa nos llevan así a ocuparnos con los círculos (a los que, como dije, designé como masas «abstractas» por su parentesco con las concretas; pero es una palabra discutible y acaso fuera mejor llamarlas latentes, como han hecho Geiger, Vleugels y otros). Librarnos de la denominación de la palabra masa para los constructos de los que vamos a ocuparnos ahora parece preferible habida cuenta de su mal uso y de que despierta todo tipo de representaciones afines pero que no tienen nada que ver.

Digamos, pues, círculos. Según acabo de decir, en ellos se prepara, bajo 
ciertas circunstancias, la acción repentina de las masas. Los círculos se muestran como constructos de duración indeterminada cuya preexistencia se da en parte en los acontecimientos masivos, pero que a la vez son, también en parte, fundamento para los grupos y las corporaciones. En ellos actúa el secreto de una alianza anímica. Destino semejante, disposiciones similares heredadas, educación parecida y vivencias previas iguales: todo ello crea una coincidencia de visiones y modos de sentir, sin que se dé (como en los grupos) una dependencia organizada. En tanto que tipos de estos constructos amorfos nombraba yo ya a: la gente sencilla, el proletariado, la buena sociedad y — para añadir un constructo particularmente difícil- el público.

Quien quiera pensar y, en correspondencia, actuar efectivamente de un modo sociológico no debería dejar de considerar a estos círculos más difíciles de abarcar y etiquetar. Desde el punto de vista jurídico, no se los tiene en cuenta al no estar organizados ni poseer estatutos. Pero políticos, moralistas, economistas harán bien en ocuparse de la presencia y la efectividad de estas «formaciones nebulosas» (Wolkenbildungen) sociales y observarlas muy a fondo, pues nos pueden traer tormentas o buen tiempo. Si no nos queremos dejar sorprender por los acontecimientos, debemos disponer de un órgano para los procesos ocultos en estos ámbitos sociales.

Para entender estos círculos debemos echar mano de un nuevo concepto: la atmósfera social ${ }^{25}$. Precisamente los círculos se caracterizan por la atmósfera en ellos reinante. Todo constructo social de alguna duración, no sólo los círculos sino también los grupos, tiene su propia atmósfera. Hay una atmósfera de cuartel, de empresa, de oficina, de café, etc. Un café vienés y una cafetería londinense, una ópera internacional y un pequeño teatro urbano tienen diversas atmósferas. ¡Y cómo se diferencian la del despacho y la del hogar!

¿Cómo surge este «estrato de aire social» (soziale Luftschicht)? Para nuestro objeto es de gran importancia, ya que las peculiaridades de lo social vienen dadas precisamente por la atmósfera entrehumana. En parte intervienen influencias naturales, externas al hombre, lo físico. Los lugares en que se desarrollan los procesos sociales, el ambiente y la iluminación, el grado de ruido o de sosiego; en resumen: los infinitos factores del mundo físico influyen poderosamente en el transcurso de los procesos sociales. Se añaden a ello las fuerzas provenientes de los círculos de relación entrehumana: costumbres, usos y ordenamientos normativos. El esfuerzo mismo por adecuarse a los fines, por ser útil en la práctica, conduce a la formación de una base de trato, entre los hombres de un determinado círculo, que imprime carácter a las relaciones prevalentes. Una vez más, la concepción meramente individual-psicológica de los hechos no es suficiente. Alguien, p. ej., puede ir a una reunión de una asociación con un determinado propósito y una actitud prevista y proceder allí según su forma de pensar y sus convicciones; se propone hablar con cierto énfasis de lo que le preocupa. Pero cuando se encuentra ante la caterva de compañeros

${ }^{25}$ Cfr. mi citado ensayo en Kölner Zeitschrift für Soziologie, 5 Jahrg., pp. 34 ss. 
constata que el estado de ánimo de éstos es contrario a sus propósitos. Cede ante esa atmósfera y calla. $\mathrm{O}$ al revés: uno se halla apocado y oprimido en un cierto instante; sin mayores previsiones, se dirige a una asamblea, pero enseguida el ambiente animado y excitante — aunque sólo fuera por la ornamentación de la solemne sala - le arrebata. Se siente otro: lo social le ha encumbrado.

Vemos, pues, cómo esta fuerza llamada lo social es algo que actúa desde fuera sobre los hombres. Pero nada podría si sus almas no fueran receptivas a tales influjos. La interioridad humana es un órgano social preformado desde los orígenes, y que muestra una mayor o menor receptividad a las impresiones de la esfera entrehumana. De nuevo la consideración sociológica y la psicológica se imbrican. Allí el camino transcurre de fuera a dentro; aquí, de dentro a fuera.

Pero a la hora de explicar los círculos y la atmósfera social resulta erróneo trabajar con la idea de totalidades místicamente intuidas, preexistentes en una región autónoma e independiente de la vida anímica del homo, y que dirigen misteriosamente a los seres humanos cuyos sentimientos sólo en apariencia serían autónomos. La atmósfera social es siempre el resultado del sentir y del pensar de antepasados que imprimieron su hacer idiosincrásico a la posteridad y delegaron su aparataje de objetos (lugares, documentos, etc.). De no haber tradición sería difícil crear una atmósfera social. No está dada de una vez por todas, sino que se desarrolla a través de costumbres. Pero, en definitiva, acaba ejerciendo una fuerte influencia sobre la conducta de las personas; conducta que siempre está influida por las dos fuerzas que la penetran: la conformación (Artung) personal y lo extra-yo (Ausserich); lo que se expresa, mejor que nada y tan inadvertida como efectivamente, a través de la atmósfera del espacio social.

\section{Las corporaciones}

Al pasar de los grupos y los círculos a las corporaciones (a las que en otro tiempo llamé colectivos abstractos), la esencia de lo social trasparece con creciente claridad. Son más detectables las múltiples presiones que ejercen sobre las personas y grupos; pero también son más indirectas, universales y menos perceptibles que los influjos que parten de los grupos. Aunque las corporaciones aparezcan como suprapersonales, no hay que caer en la idea, tan frecuente, de que se trata de sustancias ideales o metafísicas. Las fuerzas humanas que actúan en ellas son las mismas que en todos los constructos sociales. Ya pueden ser bien las imágenes idealizadas (Idealbilder) que se constituyen desde nuestra pretensión de crear un orden social perfecto, bien conformaciones posteriores de pasajes religiosos reiteradamente soñados (como en el caso del Reino de Dios, de la Isla de los Justos, el Elíseo): la realidad de los estados, iglesias y otras asociaciones nos muestran todos los rasgos propios de las debilidades, los vicios y las brutalidades del hombre; pero también los del esfuerzo por perfeccionarse y por conjuntar la fuerza de voluntad y el anhelo de una vida comuni- 
taria. Las corporaciones son logros característicos de los hombres que las construyeron en el pasado y siguen aún rehaciéndolas en la actualidad. Si queremos entender las fuerzas del estado, el pueblo, la iglesia, el círculo cultural, debemos quedarnos siempre en el ámbito del comportamiento humano. Sobre esto escribí en mi Sistema: "Del trato interhumano no pueden emerger fuerzas más sublimes, moralmente mejores, que aquellas que puedan surgir desde las mismas almas de los hombres. El mismo hecho de la existencia de las agrupaciones y formaciones de constructos duraderos es el que logra fortalecer las potencias humanas preexistentes. La comunidad (Gemeinschaft) no es, propiamente, ninguna nueva potencia axiológica (Wertpotenz). Ello siempre depende de en qué consista y para qué se dé la asociación. Puede ser sublimante y motivadora. La glorificación que hoy suele hacerse de la socialización y de la unión, sin más, es tan falsa como lo sería el elogio a secas de la soledad. Es bueno para el éxito de un trabajo ponerse de acuerdo. Pero si lo que se propone lograr en común es una canallada, contiene más valor el asumir una contradicción que desgarre la concordia $»^{26}$.

Pero una cosa es la apreciación ética, que no puede ni sobre ni subestimar a las coporaciones - lo que tampoco debe hacer esa apreciación a la hora de dirigir la atención a lo bueno o lo malo del hombre concebido como tipo- y otra su consideración como núcleos de fuerza (Kraftkerne), almacenamientos de fuerzas (Kraftaufspeicherungen) o reservas de fuerzas. De hecho, son suprapersonales y sobreagrupadoras (übergrupplich) (aunque no suene bien la palabra) en lo que respecta a su duración temporal y a la concentración de esfuerzos humanos que reúne para llevar a cabo realizaciones grandiosas. Los grupos, incluso los más grandes, no bastarían para ello. Dependen en exceso de personas fugaces, sirven mejor para los fines transitorios de hombres que buscan su propio interés. Las grandes alianzas, en cambio, tienen como tarea transmitir a los que vengan después — no sólo a hijos y nietos- lo que una generación ha logrado. Teóricamente son "eternas», si es posible usar esta palabra para realizaciones meramente terrenales y pasajeras; en efecto, semejantes realizaciones históricas no dejan de llevar, como todo lo terreno, los rasgos de lo transitorio; estados, iglesias, escuelas o logros estéticos perecen como perecen los hombres. El imperio romano, Bizancio, el comercio mundial de Venecia transcurrieron; Prusia ha sido aniquilada tras la segunda guerra mundial. En su lugar surgieron nuevos estados; pero la idea de estado, esto es: el colectivo abstracto, ha seguido perviviendo; de igual modo continúan las asociaciones religiosas como tales, aunque las iglesias conocidas históricamente hasta hoy desaparecieron. Empero, ¡cuán antiguas y graníticas son la Iglesia católica y el Islam!

Así, los constructos típicos de la vida política, religiosa, económica, estética y científica se nos muestran como las formas generales y abstractas de las configuraciones (Gestalten) históricamente variables que son cada uno de los estados, iglesias, etc.: antiguas como el hombre, persistentes en un largo futuro.

${ }^{26}$ O. c., p. 510. 
Y, sin embargo, también ellas dependen de la voluntad colectiva de los hombres; dejarían de existir si fueran presa del convencimiento generalizado de su superfluidad. Mientras se tenga por necesario centralizar la regulación del poder habrá estado; y habrá iglesias si se sigue pensando que la entrega a lo sobrenatural precisa también de una regulación colectiva. Es concebible igualmente que se dé una progresiva brutalización espiritual de un hombre que tenga por superflua a la ciencia y al arte acabando con ellos. Hasta las últimas formas generales de constructo social pueden deshacerse; tan sólo las plasmaciones del quehacer social, en el «a favor» y en el «en contra», permanecen, mientras haya hombres con diferencias individuales.

Hay que decir que mientras los hombres lo quieran, los colectivos seguirán existiendo y configurando el ser humano. Son sus creaciones, el contenido de sus ideas; de nada le sirve al hombre particular levantarse contra el suprapoder de las corporaciones mientras los demás quieran que se den y actúen. La posibilidad de la continuidad de determinadas corporaciones viene dada por $^{27}$ : 1) si la corporación es útil, o 2) satisface los apetitos de los hombres, o 3) es acorde con las exigencias morales de la gran mayoría, o 4) si no hay nada que colocar en su lugar y la costumbre está a su favor. Basta el gran respeto que los más de los hombres tienen a sus ininteligibles, misteriosas y supravitales (überlebensgrossen) corporaciones para que se mantenga su señorío sobre la criatura humana. Para dar razón de ello no basta, en absoluto, con decir que estamos ante engendros de cerebros humanos y que, además, se da la circunstancia de que miles de miles de cerebros vienen trabajando en ello desde siglos, lo que bastaría para inspirarles temor y admiración. No: la mayoría de los hombres no tienen nada que ver con semejante elaboración; simplemente se han dejado dominar acrítica y voluntariamente. Pero sus angustias y necesidades, sus veleidades y querencias, sus fantasías y sus sueños declarados son los que han colaborado en la construcción de corporaciones.

No hay que dejar de contemplar la posibilidad de que llegue un momento en que los hombres rechacen a las corporaciones, en la medida que éstas se propaguen corporalmente. Con la (desde una suposición fantasiosa) simple decisión compartida por todos de renunciar a la procreación y al nacimiento, bastaría para encontrarnos ante el fin de los constructos sociales. Estos no sobreviven al hombre por más que nos lo pretenda hacer creer esa forzada especulación que sostiene también que la sociedad, el vínculo universal de todo constructo social, sea más antigua que los hombres.

Todas estas consideraciones, tal como las acabo de exponer, y que de alguna manera rebasan el mundo de nuestra experiencia, únicamente persiguen: de un lado, hacernos presente la naturaleza humano-terrenal de las corporaciones; de otro, poner de manifiesto cómo, sin embargo, lo social alcanza en ellas una terrible potencia. Es verdad que en el análisis de las mismas no debemos perder de vista la conexión con el fondo originario de todo lo social, con el alma de

${ }^{27}$ Cfr. System, p. 525. 
los hombres; pero los hechos psíquicos han tenido que asumir muchos vínculos con la facticidad objetiva de situaciones variables; en tal abundancia (¡muchos milenios!) y con tales efectos que lo anímico-individual se manifiesta en las corporaciones radicalmente cambiado. Se podría expresar así, en formulación matemática: los constructos sociales de cualquier clase surgen y actúan a partir de complejos situacionales multiplicados por complejos motivacionales, esto es, por factores anímicos. He usado la palabreja por, subrayándola, y no "plus»; hubiera podido decir también "potenciados», para dar a entender que con cada proceso social tiene lugar un acrecentamiento constante de la transformación de lo individual en lo social.

\section{La sociedad}

En este primer capítulo he intentado explicar qué se entiende por lo social; en él me he esforzado en conducir al lector a través del laberinto que lleva desde los procesos sociales hasta los grupos, masas, círculos y, finalmente, las corporaciones; procede, para concluir, hablar del constructo universal que se denomina con la palabra sociedad.

Si pudiera atribuir la condición de sustancia a los constructos sociales haría culminar mi tarea en dar testimonio de este "organismo", abarcador de todos los demás colectivos y del que los mencionados constructos sociales no serían sino órganos y miembros. Y si tal interpretación fuera correcta habría hecho mejor arrancando de esta sustancia general, empezar por describirla a ella y caracterizar luego los constructos especiales que derivan de ella ordenándolos según esta dependencia.

Pero del mismo modo que en todo lo ya escrito rechacé que se considerara a los constructos sociales como sustancias, ni siquiera incorpóreas o espirituales —o, como hoy gusta decirse, "totalidades» (Ganzheiten)—, tampoco hay que considerarlas como tales cuando se trata del constructo universal «sociedad».

Pero no podemos prescindir por completo de esta palabra, aunque sólo sea como nombre abreviado para el conjunto de todos los procesos y complejos de procesos que se denominarán como sociales. Se trata de una mera exigencia terminológica, no de una necesidad conceptual. Sería fácil pero engañoso que yo pretendiera seudodefinir nuestro objeto, lo social, en cuanto característica unitaria de un universo cósico, como sociedad; simplemente: todas las determinaciones esenciales habría que desplazarlas a la interpretación de este sustantivo «sociedad».

Las representaciones vinculadas al uso de la palabra sociedad (aquí se entiende sólo el uso sociológico, no, p. ej., el jurídico, el económico, ni siquiera el «social») proceden en lo fundamental de la teología, de la medieval sobre todo. El cristiano creyente creía y cree en el reino de Dios o del diablo, en una comunidad con el padre celestial o con Satán, que configuran un constructo 
social metafísico jerárquicamente escalonado. En el fondo, la representación de una sociedad descansa en un acto de secularización de este reino religioso e invisible creado por la fe. El largo adoctrinamiento del pensar y el sentir al servicio de la religión preparó la disponibilidad de los hombres para representarse un reino universal terrestre - no de Dios ciertamente, sino de hombres falibles-. También la vida burguesa, sin embargo, andaba cerca de este operar con el concepto de sociedad. El derecho, que creó las «sociedades» anónimas; la economía, que descansaba en buena parte sobre asociaciones de carácter individual; la política, que estado y pueblo se traen entre manos..., y muchas cosas más, operan todavía con la representación de un universo general pero sustancial.

En el siglo XVIII y al comienzo del XIX se empezó viendo este universo en el estado o en el pueblo. Los románticos prefirieron el pueblo; los idealistas, Hegel particularmente, el estado. Enseguida surgió la idea de sociedad burguesa; pero no entendida como un círculo más amplio que el estado, al que abarcaba, y opuesto a él, sino como un campo dentro del estado en el que se desarrollaba la vida social y económica y en el que la fuerza reguladora era la costumbre y no el derecho público. La concepción de las relaciones entre estado y socidad sólo se modificó a partir del desarrollo por parte de Augusto Comte de la sociología, definida a menudo, de modo significativo, como ciencia de la sociedad. Esta no aparece ahora ya meramente como «burguesa», sino como el universo de lo entrehumano en general; pero no entendido como un ámbito de fuerzas y procesos, sino como un ser, un todo cuya universalidad sólo podía ser comprendida en contraposición a la naturaleza perceptible. Aún no se tenía muy claro que semejante concepción derivaba de ideas religiosas y había sido transferida al mundo profano; pero, especialmente en Alemania, el impulso hacia la metafísica y la tendencia a la especulación sobre lo imperceptible se empezó a detectar con fuerza en las fantasías, que aún sobreviven, acerca de la fuerza sobrehumana y que va mucho más allá de las almas individuales de una —diría yo- divinidad terrestre.

Precisamente he intentado ya menudo mostrar que los constructos sociales no son simples amontonamientos o adiciones de procesos, sino que con cada una de estas sumas se crea algo nuevo imposible de constatar, con igual fuerza y de la misma manera, en los seres particulares por separado. Si ello es así tratándose de grupos, círculos y corporaciones, ¿cómo no lo sería cuando va del universo de todos los constructos, esto es: de la sociedad? Y si el estado o el pueblo son entendidos como totalidades, ¡cuán fuerte no será la inclinación a entender como sustancia espiritual la fuerza terrestre más general de todas, la sociedad!

Ni tampoco habría ningún fundamento decisivo para volverse contra esta ficción; facilita la comprensión de lo social. Sólo que la experiencia enseña que tal cosificación encierra un gran peligro. Como quiera que la sociedad no es perceptible (a la manera del sol) y puesto que no es demostrable como totalidad, podemos atribuirla, por poca fantasía que tengamos y sin intentar prueba 
alguna, cualesquiera posibles cualidades, requerimientos, presuntas metas o tendencias. En realidad, nos enfrentamos tan sólo a innumerables complejos de procesos, contradictorios entre sí y de hecho verificables; basta con destacar, aislándolas, algunas de estas situaciones e ignorar todas las demás para convertirlas en las manifestaciones y fines de la sociedad. Se puede entonces predicar de ella todo lo que se corresponda con los propios deseos y temores del intérprete; y en la medida en que, presuntamente, lo exige el sentido de la sociedad, atribuirle a éste la máxima autoridad. El abuso ejercido fuera del ámbito de lo religioso en la historia de la humanidad a cuenta de lo indemostrable y pretendidamente suprahumano es inconmensurable. En nombre de la sociedad se pueden plantear a los atormentados seres humanos exigencias que, una vez desenmascaradas, se descubren como pretensiones de unos o de otros gremios de interesados. Pero la sociedad no es un ser que quiera algo, aspire a algo o se desarrolle; en su lugar se da lo social, que no estriba en nada externo a las almas personales de los hombres, sino que actúa en ellos como una fuerza especial junto a los impulsos, sentimientos y representaciones puramente individuales. Es en el interior de los hombres donde se da lo colectivo, el poso de las influencias que remiten a la existencia de otros hombres, antes, junto y después del singular concreto. Ello es el resultado de la circunstancia de que cada yo no es sólo poseedor de muchas experiencias, vivencias y cualidades propias, sino que las comparte con el «homomundo»(Homo-welt); con la particularidad de que son aquellos hombres que pertenecen al círculo estrecho de nuestra vida los que, por regla general, ejercen influjos más similares que los que están lejos. El homo vive tan sólo vinculado con otros homines. Desde milenios, infinitas e inabarcables influencias transitan de unos a otros y crean esta red de relaciones a la que llamamos sociedad. En definitiva, se la puede reducir a procesos sociales y explicarla a partir de ellos, esto es, a partir de los procesos de aproximación y alejamiento de los hombres; pero subrayando entonces «en definitiva»; pues entre la infinitud de las influencias que los hombres ejercen entre sí y el universo-sociedad se encuentran los constructos sociales escalonados de muchas formas; y no son meramente los procesos inter-individuales los que llevan a la representación de la sociedad, sino sobre todo y en complejidad creciente los procesos entre grupos, círculos, corporaciones. Se la podría comparar con el cosmos natural, en el que los astros giran según la ley de la atracción y la repulsión; sólo que semejante alegoría encierra el peligro de volver a conjurar la idea de un universal sustantivo (Universal-Substanz).

¿No deberíamos decir humanidad en vez de sociedad? Haríamos así más plástica la idea, correcta, de que precisamente en este universo humano (Mensch-All) se trata siempre de homines sapientes y su vida interior. Pero también así reaparece el peligro recién mencionado de la sustantivización de lo entrehumano. No se trata de suma de cuerpos, sino de fuerzas, comparables al juego conjunto de los electrones en el átomo.

Con esta concepción realista de la sociedad hemos logrado una elaboración más clara de lo social. No solamente nos hemos librado, gracias a ella, de ima- 
ginaciones fantásticas e inveraces (¿no ciertas?); a nuestro logro teórico le acompañan progresos prácticos, es decir, éticos, estéticos y políticos. Las normas nacidas de tal concepción no son producto de una especulación egoísta e interesada, sino resultado de la observación de la vida real. Constituyen exigencias que ennoblecen la zona de lo entrehumano, puesto que semejante concepción nos permite cultivar y favorecer los procesos sociales más adecuados; busca el grado de unión o separación más fructífero en cada caso sin sucumbir a la locura de un ideal creado por prejuicios; sin perder nunca de vista la imagen decisiva del singular, pero sin limitarnos tampoco a la consideración de lo personal sin más. ¡Yo soy yo! encierra tanta verdad como: ¡Yo soy tú, y todos juntos somos nosotros (wir), un Nosotros (Wir)!

El hombre particular no crece tan sólo en un círculo de personas perceptibles para él, sino en una atmósfera anímico-espiritual que está hecha de costumbres y usos, reglas y leyes, opiniones y convicciones, rutinas y expectativas que se han ido formando en el transcurso de milenios a partir de miles y miles de millones de procesos sociales. Los residuos que todos estos procesos han ido decantando en la atmósfera social forman un aire (no respirable con los pulmones de nuestro cuerpo) que nos ambienta desde que nacemos, y cuya composición y movimiento no cesan de cambiar. Es comprensible que el pensamiento abstractivo se esforzara por desprender en cierto modo de las cosas aprehensibles esta atmósfera, llamada la sociedad, o mejor lo social, y la convirtiera en objeto de una ciencia propia. Los sociólogos son astrónomos y meteorólogos del mundo de lo entrehumano.

\section{EL AMBITO PRIVADO Y PUBLICO EN LA VIDA HUMANA}

\section{Observaciones previas}

Como anteriormente con el par, los grupos, los círculos y las corporaciones, cabría decir ahora no poco sobre los subtipos y sobre la evolución histórica de los constructos sociales en su conjunto; pero me parece aconsejable abordar todavía, bajo otro punto de vista, la tarea aquí acometida: la comprensión de la esencia de lo social; no se trataría ya de la contraposición individualcolectivo, sino de la de privado-público, estrechamente emparentada con aquélla. Sin embargo, en cuanto a la extensión no son iguales individual y privado, ni colectivo y público. A medida que vayamos ahondando en los conceptos «privado» y "público» iremos viendo claramente que privado es una subcategoría de individual y público una variante de colectivo. También, el énfasis con que se destaquen ciertas características se desplazará según que usemos una u otra de estas dos palabras. Pero, en definitiva, se trata siempre del significado de lo social y de lo no social. Las ideas de polaridad, reciprocidad y totalización, vinculadas ya anteriormente con los conceptos individual-colectivo 
(social en el sentido estricto de la palabra), nos acompañarán también ahora, al ahondar en la correspondencia y en la diferencia privado-público.

\section{La relación de contraposición entre el ámbito público y el privado}

De inmediato y para empezar, permítasenos formular el Leitmotiv de esta segunda parte: ámbito privado y público están estrechamente entrelazados. Forman dos corrientes que se alimentan de continuo entre sí. La esfera privada existe por la pública y la pública por la privada. Pero no se trata de la mera relación de contraposición entre dar y recibir, sino de la de interpenetración de ambas. Si se me permite una imagen: la vida real es de color lila, cuyos elementos son el azul de la esfera privada y el rojo de la pública. La intensidad del color varía constantemente; el ojo del espectador percibe unas veces más el rojo y otras más el azul.

Ambos ámbitos se encuentran el uno con el otro en la relación de medio a fin. En ocasiones, lo social externo al yo, lo público, es visto como el campo de acción que se brinda a la persona; en ocasiones, el hombre parece no ser sino el instrumento para el logro de fines sociales y, por tanto, de lo público. Unas veces las capacidades, dotes y carencias individuales son consideradas como algo privado; otras veces son entendidas y juzgadas desde el punto de vista de las necesidades públicas. Quien escoja unilateralmente el modo de considerarlas y la motivación puede verse acusado de argumentación falsa precisamente por unilateral. Un ámbito está siempre completamente abarcado y circunscrito por el otro. Georg Simmel, cuando entra en el debate sobre si la asistencia a los pobres habría de ser pública o privada (en una breva nota) ${ }^{28}$, se refirió en el mismo sentido a esta subsunción de la constitución de lo individual bajo la constitución de lo social «en la que penetra tanto la raíz como el fruto (de la configuración privada)». Constituyéndose una relación que "puede invertirse exactamente bajo la misma forma». «Si el individuo — prosigue Simmel— aparece, por un lado, como una especie de mero constructo-tránsito (Durchgangsgebilde) de lo social, del mismo modo, lo social puede funcionar como simple instancia mediadora del desarrollo individual. Por otro lado, en el otro extremo de nuestra existencia exhibimos de modo igual una apariencia o un complejo de apariencias, que nos hacen inclinarnos a observar lo social a partir de lo individual, en tanto que lo individual se muestra como lo más externo, lo más precisado, lo más conformado, como si fuese aquello para lo cual aconteciera ese estar-ahí.»

Estas observaciones (de difícil formulación) tienen estrecha relación con las ideas básicas que aquí se han tratado; en Simmel se entremezclan en investigaciones en las que el punto de vista del conjunto social se contrapone a enjuiciamientos que arrancan de la consideración previa de la persona; p. ej.: el cas-

${ }^{28}$ Cfr. Soziologie, Leipzig, 1908, p. 483, nota. 
tigo que puede ser visto desde el crimen (aspecto público) o desde el criminal (aspecto personal). De igual modo, y a propósito de la lucha contra la pobreza, tan pronto se la ve desde el punto de vista del pobre como se la considera en tanto que situación social.

Surge aquí de inmediato un segundo hecho: ambos ámbitos no son provincias vecinas sin más o, considerado cinéticamente, corrientes que discurren paralelas; se entretejen de manera tal que lo que parece público bajo cierto punto de vista, vale como privado bajo otro. Qué ha de adscribirse al campo de lo público y qué al de lo privado varía según los casos. Se dan tomas de posición cambiantes derivadas unas veces de aquel punto de vista y otras de éste. Es como un podio desde el que hablan oradores que van sucediéndose y a los que oímos sacar conclusiones con frecuencia contrapuestas.

Para una sistemática que etiquetara con superficialidad, las grandes corporaciones pueblo, partido, iglesia, cultura, estado y municipios, sobre todo, constituirían la esfera pública; la familia, la vecindad, las pequeñas relaciones comerciales y otras similares pertenecerían al ámbito privado. Un análisis más profundo nos enseñaría, sin embargo, que ni siquiera el yo solitario puede ser tenido siempre por privado; en su alma también luchan lo privado y lo público. Por el contrario, tiranos y autócratas consideran más o menos como asunto privado hasta al mismo estado; no pocos príncipes de la iglesia, profetas y jefes de sectas entrelazan tan estrechamente su empeño personal y su particular deseo de salvación con su confesión que acaban teniendo a la iglesia o la secta como su dominio privado. Es el caso especialmente de los jefes de los partidos. En el arte y las ciencias suelen ser las personalidades más productivas, aquellas totalmente entregadas a su tarea, las que vinculan más estrechamente lo privado con el servicio a lo público. En comparación con el pueblo, el estado y la profesión, no hay duda de que la familia representa por antonomasia el ámbito de lo privado. Y, sin embargo, no es raro que un padre de familia solícito por el cuidado de los suyos, o el hijo ya criado que desearía andar su propio camino, consideren la familia como una esfera que actúa desde fuera con cierta coacción social, al modo de la esfera estatal con su poder público.

La «sociedad» no para de asimilarse pedazo a pedazo la zona del yo oprimiéndole bajo sus normas y valoraciones.

Tomemos como ejemplo de este entrelazamiento de los dos ámbitos el destino individual medio de un hombre que busca trabajo, existencia segura y felicidad. Podemos distinguir en su trayectoria tres estadios: de entrada le mueven empeños subjetivos y personales. Pero pronto se da cuenta de la imposibilidad de satisfacer semejantes deseos del ego sin el reconocimeinto, la oportunidad y el apoyo de todo tipo: sin la huida hacia lo público. Entra entonces a su servicio, se esfuerza en acomodar sus dotes personales a las exigencias que aquél le plantea, en hacerse útil y satisfacer las aspiraciones del «extrayo» (Ausserich). Lo privado se ha vendido a lo público. Pero ahora y por regla general la gratificación se queda corta. La "publicoidad» se toma la «revancha». Alcanzamos entonces el tercer estadio. En casos favorables los deseos privados 
pueden ser colmados. Es verdad que entretanto el yo, al servicio de lo colectivo, está marcado y configurado de tal manera que se ha convertido en un producto de las influencias públicas y del yo primigenio (las más de las veces reducido). Semejante resultado no puede entenderse sin recurrir a las fuerzas del otro ámbito; cada uno de los dos ha recibido tantos influjos del otro que ya no existe en su estado puro. Con razón habla Simmel ${ }^{29}$ de la «sustancia básica individual de la personalidad»; sustancia que no nos sería posible captar en su pureza y más allá de su configuración por el milieu histórico, sino que la sentiríamos sólo como el material permanente de nuestro ser personal y como la suma jamás agotada de sus posibilidades. A mi juicio, se expresa aquí con singular penetración toda la problemática, tan difícil de penetrar, de la relación entre hombre y sociedad.

Con lo que se plantea la cuestión de si es correcto hablar, como hacemos en el título de este capítulo, de ámbitos privado y público, de esferas y círculos; de si la sociología está en condiciones de abordar lo público y lo privado en cuanto constructos sociales, es decir, de representárselos como conglomerados de procesos sociales que discurren hasta cierto punto de manera semejante, como sería el caso del estado, la iglesia, la empresa, el partido, etc. En efecto, aquéllos no son en absoluto círculos delimitables que podrían ser certificados con el nombre constructo social. Si, para comprobarlo, nos atenemos a locuciones cotidianas (como "se dirige al público», "se retira a su vida privada", etcétera) parecería como si nos representásemos dos mundos separados cuyas fronteras fueran ciertamente franqueables. De hecho, en el uso verbal, estado, comuna, iglesia, economía se equiparan con público; familia, compañeros..., con privado. Publicoidad se equipara frecuentemente con publicum, incluso con «sociedad burguesa». Cuando alguien escribe a un periódico se dirige al público: se hace la idea de que sale de una relación familiar u ocupacional más restringida para dirigirse a otra esfera indeterminada pero más fuerte, con más autoridad, y a la que atribuye una capacidad de decisión mejor fundada.

La jurisprudencia y la economía lo tienen más fácil que la sociología, cuyo análisis debe ahondar más. El derecho, limitándose a la superficie organizada de la sociedad, puede separar dos ámbitos delimitables con relativa fijeza: derecho público y privado; allí las normas que se refieren a las relaciones de las personas con el estado o de los estados entre sí, aquí las reglas jurídicas que determinan las relaciones de las personas entre sí y la posición jurídica de cada persona en particular. Son dos ámbitos, en principio aunque no siempre en la práctica, perfectamente delimitables. Dígase otro tanto de la separación entre economía privada y pública, cuyo tratamiento ha crecido tanto actualmente y crece a diario. Pero ello es posible sólo porque se limita al concepto de publicoidad en tanto equivalente al de estado u otros constructos similares a éste. Pero en cuanto se trata no de estado sino, p. ej., de arte, ciencia, amor o amistad, vida cotidiana y, sobre todo, profesión, la delimitación estalla. Así cuando

${ }^{29}$ Cfr. o. c., en la nota de la p. 483. 
se dice: ésta es mi opinión particular, pero me la callo en público; o cuando se dice de alguien: en privado es comunicativo y locuaz pero en público se cierra. Casi siempre, en estos casos, se trata de la oposición entre profesión, de un lado, y familia o esfera social, por otro.

\section{Aclaración de las palabras público y privado; definición de ambos conceptos}

Después de todo lo dicho, ¿se puede asimilar "privado» a «lo que se refiere a la propia persona", como hace el Léxico de conversación de Brockhaus? ¿Se entiende con ello exclusivamente la esfera del ego? El uso lingüístico lo contradice: círculo privado, empresa privada, etc. En estos casos el pronombre subyacente es en cualquier caso «nosotros», no "yo». Habría entonces que añadir a la recién citada definición de Brockhaus: lo "privado» puede remitir bien a la propia persona o a las propias personas. De todas maneras, no hay por qué pensar que esté en juego sin más el egoísmo o el egotismo; un círculo privado, p. ej., puede consagrarse al cuidado del bien común.

¿Qué nos enseñan otros diccionarios? Remitámonos de inmediato a la fuente de las fuentes, al diccionario alemán de los hermanos Grimm ${ }^{30}$.

De entrada se citan en él como sinónimos: privado, sin cargo, particular, íntimo, no público, personal, doméstico; en general: lo opuesto a con cargo, público, general, común. En el siglo XVI se establecen a partir del latín privatus las equivalencias: independiente del estado, que no vive de un cargo, concerniente a una persona en particular. Desde entonces su uso ha crecido mucho. Citemos algunas conexiones un tanto singulares:

Christian Weise (nacido en 1642 en Zittau), que escribió novelas satíricas, hablaba de alguna "pequeña gente: sujetos tales que no mezclan sus cargas privadas (más tarde domésticas) con las públicas». Las referencias en los siglos XVIII y XIX son inagotables. De entre los muchos ejemplos del diccionario baste entresacar a Kant: «iY no es lo inmejorable del mundo (Weltbeste) en tanto que idea, algo que nos puede hacer daño al logro de lo inmejorable privado (Privatbeste) de nuestro ser?» O Schiller: «a los ladrones privados se les encarcela de por vida mientras los públicos andan por ahí envueltos en oro y plata». Para acabar he aquí seis significaciones diferentes de público:

1) conocido por todos, claramente manifiesto (anticuada);

2) sin reserva (ohne Rückhalt), sincero (anticuada);

3) no secreto, sino que es o sucede a la vista de todos;

4) abierto (economía doméstica abierta, mercados abiertos, etc.);

5) en oposición a privado: no para cada uno en particular, sino para muchos o para todo el público (p. ej., culto religioso público);

${ }^{30}$ En 7 vols., Leipzig, 1889. 
6) en especial: concerniente a una asociación grande, a un municipio o un país.

De todas estas interpretaciones son la tercera, quinta y sexta las que nos conciernen.

Es muy digno de atención lo que Mussman, ya en el año 1830, en la Enciclopedia general de las ciencias y las artes, fundada en 1848 por Joh. Sam. Ersch y Joh. Gottfr. Gruber ${ }^{31}$, dijo sobre lo público. Este artículo, escrito hace más de ciento veinte años, tiene un aire moderno y sociológico, aunque realmente de difícil formulación: «si la última (privaticidad) expresa una actividad o, en general, la determinación de algo que es efectivo no para la generalidad, ni para una comunidad social en su conjunto, sino inmediatamente o por lo pronto sólo para cada uno o para pocos, entonces la primera (vida social pública/Öffentlichkeit) ${ }^{32}$ es lo opuesto: lo que concierne a la generalidad, o se refiere a lo que es importante para el pueblo o para la humanidad en conjunto». Hace equivalente "publicoidad» (Öffentlichkeit) a «notoriedad pública» (Publizität); y prosigue: «no necesita probarse que el hombre como ser racional, ciudadano del mundo y del estado que es, está realmente determinado también por la naturaleza a llevar una vida tanto pública y general como particular y casera». (Más bien creo que es esta duplicidad de la vida humana lo que constituye un problema que debe ser investigado y no dejado de lado.)

31 Siete vols., hasta 1890 .

32 Nota del traductor: Este término es traducido en numerosas ocasiones simplemente por «lo público", e incluso inadecuadamente, recurriendo sin más a una compleja categoría sociológica, por "opinión pública». Y es que existe una dificultad añadida en la traducción que reside en que el término Öffentlichkeit mantiene aún ese significado originario de la palabra decimonónica Publizität, que es precisamente el de "vida social pública». (Pensando en ello traducíamos en la cita de 1848 Öffenlichkeit con el antiguo, pero actualmente equivalente, significado de vida social pública.) Incorporada aquélla en el siglo pasado a partir del francés publicité, pasa a ser germanizada sin alterar su carga semántica; en cambio, todos los idiomas latinos van modificando a lo largo de nuestro siglo su significado, pasando por el de «notoriedad pública», hasta alcanzar la significación actual de "lo publicitario» o «lo publicístico»: al quedar «lo público» vinculado a la función de reclamo ejercida por los mass-media. No obstante, en los países de habla germana, todavía hoy sigue en circulación la voz más primitiva de Publizität, a la que se refiere aquí Wiese; por lo que esta voz habría de ser estrictamente vertida a nuestro idioma —al hilo de lo dicho, en tanto que concepto en transición- por notoriedad pública. También desde una óptica sociopolítica se puede decir que, actualmente, Öffentlichkeit queda referido adecuadamente con la locución de "vida social pública», en donde confluyen la noción más político-moral de "vida pública» y la más sociológico-espacial de «espacio social». En cualquier caso, es claro que el concepto incorpora a su significación la presuposición básica de que existe algún "público» de élites, ciudadanos, multitudes, muchedumbre, masa, etc., en tanto que sujeto portador o sustentador de aquel «lo público»; en este sentido proponemos aquí una traducción alternativa de Öffentlichkeit que, aun desde nuestro siglo, que es el de Wiese, nos recuerde la compleja evolución del fenómeno. Para ello acuñamos el término acrónimo-sincrético de publicoidad, que nos remite simultáneamente a "lo público», "al público» y a "la sociedad de la publicidad». Decir, por último, que, dada la relevancia de estos matices, usaremos en lo que sigue alternativa y selectivamente los términos castellanos aquí citados. 
En el gran Herder se equiparan breve y categóricamente privado y propio, doméstico, personal.

(Dicho sea de paso que lo que los diccionarios dicen sobre la opinión pública o sobre el público es más que insuficiente ${ }^{33}$.)

La escapada a la interpretación verbal no nos lleva a la meta por más que no pocas de las mencionadas equivalencias con otras expresiones ilustren bien uno u otro aspecto. Es el caso de lo secreto (geheim) y privado (privat) o de lo desocultado (unverborgen) y público (öffentlich). Y, en efecto, a una carta confidencial, dirigida en exclusiva al interesado, se la apostilla con privatim; una exteriorización privada no debe extenderse; un secretario privado está obligado al secreto. Por otra parte, se cuenta con que lo que se dirige a la publicoidad encuentre eco y no se mantenga en secreto.

Pero demorémonos un instante en expresiones emparentadas. ¿Cómo se las ha la palabra, derivada del griego, esoterisch con privado y exoterisch con público? Aquélla significa: (con)sagrado; ésta: no perteneciente a círculos estrechos. Está claro que no se puede equiparar esotérico con privado ni exotérico con público. En cierto sentido, quien se introduce en los secretos de una comunidad queda fuera del aislamiento privado; es verdad que semejente círculo más íntimo (p. ej., en los antiguos "Misterios») se opone a la publicoidad general como algo privado (incluso íntimo o secreto). Viceversa, vale otro tanto para «exotérico». Pero es perfectamente posible caracterizar determinados rasgos de lo esotérico como "privado" y, de forma correspondiente (si bien en menor grado), no poco «exotérico» como no íntimo, entregado a la publicoidad.

¿Qué decir de los hoy tan predilectos vocablos del psicólogo C. G. Jung, extravertido e introvertido ${ }^{34}$. Aquél significa vertido hacia fuera; éste, hacia dentro. De hecho, me parece que un análisis anímico, inclinaciones y comportamientos privados remiten a la introversión; a su vez, la exigencia de obtener logros públicos corresponde a la extraversión. También aquí se pone de manifiesto que las expresiones correspondientes no se pueden utilizar en absoluto como sinónimos, lo que no obsta para que en determinadas investigaciones especiales valga la equivalencia.

Lástima que en alemán la extensionalidad de la palabra "privado» permita hablar de "comportamiento privado», mientras que la restrictividad de la palabra "público» no lo permite para "comportamiento público»; mejor sería decir «comportarse en público» o «comportamiento tendente a la publicoidad».

Cabría, por fin, interrogarse sobre cómo se las ha lo privado respecto de lo "oficial». Realmente se pueden contraponer los conceptos privado y oficial (esto es: burocrático —ämtlich_); pero público y oficial no significan uno y lo mismo. De las indagaciones que siguen se desprenderá que lo público rebasa con

33 Valga mencionar, no obstante, que el Herder-Lexicon dice muy acertadamente de la opinión pública que contiene, en parte, estados de ánimo, deseos y, en parte, juicios determinados.

${ }^{34}$ No entiendo por qué Jung y sus partidarios dicen extravertido y, en cambio, introvertido? ¿Es mejor latín? ¿No se puede decir intravertido? 
mucho lo burocrático. En las exposiciones sobre los ámbitos se tratará de relaciones que en parte — sobre todo si va de la esfera estatal — podemos caracterizar como burocráticas. Pero la vida burocrática no es sino un apartado de la pública.

Si se hiciera una estadística sobre la frecuencia de los significados de ambos términos se llegaría, sin duda, al resultado de que, en la mayoría de los casos, "público" se usa como equivalente a "desoculto", y "privado" a "separado" (abgesondert). Así, cuando se caracteriza el envidiable estilo de vida de los pueblos del sur, al aire libre y sin las estrecheces de la vivienda (en la calle, p. ej.), como "público». También Goethe habla en su Viaje a Italia de la «vida pública» de los italianos (no sin lamentar el penoso clima nórdico).

Puesto que está claro que ambas expresiones se usan en sentidos muy distintos y con diferentes características, ¿no se debería renunciar a las definiciones y con ello a un uso rigurosamente científico de tales palabras?; ¿eliminarlas de la sociología? Perderíamos mucho: la oposición público/privado es tan esencial y rica como indispensable para el entendimiento. Su uso es tan frecuente y dominante en la praxis que sería repudiable desconsiderar en la teoría lo que en la vida cotidiana se prefiere. Hay que contar, sin embargo, con el doble sentido de las palabras que constituye precisamente una muestra ejemplar para la relación nada transparente entre sustancia y proceso: publicoidad y privaticidad son en ocasiones denominaciones de dominios objetivos de la vida, sobre todo, como dijimos, para la esfera estatal, en un caso, y para la personal, en el otro. Pero a menudo son expresiones que caracterizan las actitudes, modos de pensamiento, reflexiones, sentimientos; en breve: reflejos anímico-espirituales. Este tránsito de los términos del ámbito de los constructos a la esfera de las reacciones psíquicas corresponde por completo a la disolución de las sustancias sociales en procesos, tal como la teoría de las relaciones sociales tiene que admitir. La cuestión no es tan sólo: dónde están los círculos de la publicoidad y la privaticidad, sino más aún: cómo se posicionan los hombres ante el curso variable de los sucesos que tienen lugar en aquéllos. La teoría de los aparentes ámbitos de la publicoidad y la privaticidad se convierte en una teoría del comportamiento entrehumano en ellos y respecto de ellos. De donde se sigue que no es posible delimitar de una vez por todas las correspondientes esferas; al contrario, a veces es una y a veces otra la que aparece como privada o pública. Con lo que no se quiere decir, de ninguna manera, que la separación de ambos complejos de fuerzas sea falsa o superflua. Al contrario: con ella ahondamos mucho más en la esencia de la tarea encomendada a la sociología y deberíamos aportar argumentaciones antropológicas, psicológicas y fisiológicas.

Desde un punto de vista científico, sobre las relaciones podríamos dar, por ejemplo, la definición siguiente: el dominio público es un complejo de representaciones consistente en una cosificación (hipóstasis) de procesos sociales muy diversos, en los que destaca el influjo de los constructos sociales sobre los procesos. La privaticidad, por su parte, sería un complejo de representaciones constituido por la cosificación de procesos sociales muy varios en los que destaca la coherencia con lo individual, lo personal, a veces lo aislado. 
En todo ello es esencial subrayar la hipóstasis así como la elasticidad e indelimitación de los ámbitos. A veces aparece algo como privado y a veces como público. Lo común a todos los tipos de publicoidad es que apuntan hacia la relación con el colectivo; en la privaticidad, hacia lo individual. Que se vea como individual o colectivo varía en cada caso. En absoluto son solamente estado y pueblo el ámbito de lo público, ni familia, hogar o la esfera del yo solitario la zona de la privaticidad. Esta contraposición, empero, es con mucho la oposición más frecuente.

\section{Dependencia y autonomía}

Queda claro con lo dicho que nuestro problema pertenece al círculo de cuestiones fundamentales de cualquier sociología general, y que conciernen siempre a la relación hombre/colectivo. Cualesquiera reflexiones e investigaciones válidas para estos temas capitales de la ciencia de la sociedad tienen aquí su campo; y las reglas básicas que establece la fundamentación de la sociología hallan aquí su constatación: en especial el principio de que persona y sociedad se encuentran en una relación de contraposición tan varia, y su ser y obrar son tan fuertemente interdependientes, que no se puede otorgar la primacía o prioridad a ninguna de ambas esferas; de tal modo que el partir del hombre individual o del constructo social es tan sólo una cuestión de pertinencia que depende de las peculiaridades de cada caso; sobre todo si se tiene en cuenta que hombre y colectivo no se hallan en la relación parte/todo. Tesis como: el hombre es un producto de la sociedad, o a la inversa: es la personalidad fuerte la que configura su círculo social según sus propios deseos y sin consideración alguna a los datos sociales, son falsas por igual. Dígase otro tanto para publicoidad y privaticidad.

Particularmente en esta problemática que nos ocupa hay que tener cuidado con deslizarse hacia una dependencia de tipo monocausal. Vale, por un lado, lo que intenté expresar en otro lugar ${ }^{35}$ : «el hombre barrunta mi destino ya que también mi vida interior está guiada por un pueblo, estado, iglesia y por otros constructos sociales que sobrepasan con mucho el pequeño círculo de mi vida». Lo que significa que también la unión del alma y del espíritu con su época, con la cultura dominante, viene dada por la evolución histórica. Esta conciencia puede llevar a que el hombre así instruido grite aterrorizado: cierto, yo no soy yo; soy lo que se hace de mí. No son sólo los constructos políticos, eclesiásticos y económicos los que configuran mi persona. Añádase a ello el influjo, en ocasiones agobiante, de lo que se llama la masa.

Y de nuevo nuestro hombre, horrorizado por semejante autorreflexión, y

${ }^{35}$ Cfr. «Psychologische und soziale Grundlagen menschlichen Handelns», en la Festgabe para Georg Jahn, Berlín, Duncker \& Humblot, 1955, pp. 589 ss. 
que detecta el poderío de la masa, exclama: ya no me reconozco. ¿Qué he hecho yo, hombre sin voluntad, como miembro de una masa?

Pero, aun prescindiendo de semejante poder social un tanto sobrecogedor, la coacción de la profesión, la obediencia de una disciplina agobiante, la función social es con frecuencia tan desmesurada que cualquier hombre que se examinara con cierta honradez confesaría: no hago ni dejo de hacer sino lo que se me exige.

En la intrincada trama de dependencia y autonomía ${ }^{36}$ diversamente escalonadas es frecuente perder de vista este tipo de individualidad; avanzada la ancianidad, nuestro hombre actual llega al fin, como el viejo Peer Gynt, a una situación en la que ya no puede reconocer él mismo sus capacidades individuales: hasta tal punto han sido transformadas por la educación, la profesión, el matrimonio, los viajes, los estudios y las apreciaciones de otros hombres.

Con todo, ¡hay que ver cómo se agarran algunas naturalezas a lo innato y heredado! ¡Y de qué forma tan diferente reaccionan a veces ante una situación determinados hombres que estuvieron largo tiempo bajo estas influencias externas!; incluso mellizos que se criaron juntos y, en primer lugar, gentes que estuvieron expuestas, en internados, conventos y cuarteles, a influencias parecidas. La individualidad no es un cuento de los liberales. Factores tan determinantes los de una escolarización concreta son los instintos e impulsos individuales, el temperamento, las disposiciones psiconeuróticas; y también el ethos personal, la distinción o la vulgaridad de pensamiento: todo ello no es, de ningún modo, un mero producto de la educación, sino que «se lleva en la sangre».

Y no pocas veces hasta el yo infiel a sí mismo, transformado casi en juego del contorno, se reencuentra (para bien y para mal). A través de las capas de una superficie socializada discurre un canal en lo profundo de su ser hasta la frontera del inconsciente: aunque sea, en ocasiones, de manera imperfecta y transitoria, acaba arrojando lejos de sí todas las costras del influjo externo con un liberador: ¡yo soy yo! Queda por preguntarse hasta dónde este yo, así descargado, no es de nuevo un producto de otras influencias sociales, las más de las veces pasadas e inconscientes para el ego. El foso enterrado en su interior lleva a profundidades de las que el propio indagador aparta su mirada desconcertado.

Aun cuando nuestro complejo de cuestiones no es sino un componente del inagotable problema hombre/sociedad, tampoco pasa de ser, sin embargo, un apartado del mismo, y, desde luego, no el más impenetrable; no hay por qué exigir, al tratar de la «publicoidad/privaticidad», un desarrollo en toda su profundidad de ese interrogante que se vierte sobre la cuestión de la individualidad; más bien, al penetrar en el dominio de lo privado, se puede dejar en paz la cuestión de cómo llega a constituirse la coherencia de los elementos de la privaticidad y la publicoidad cuando se encuentran demasiado embarullados.

${ }^{36}$ Cfr. mi introducción en la obra conjunta Abhängigkeit und Unabhängigkeit im sozialen Leben, Köln und Opladen, 1951, pp. 33 ss. 
El problema que nos obliga no es tanto el cómo ha surgido cuanto el de cómo actúa. El surgimiento de su contenido: juicios, convicciones, aspiraciones, se asemeja a la formación de las capas de la corteza terrestre; sólo que aquél no se lleva a cabo con tanto orden ni es tan comprobable. El yo y el ámbito privado reciben el material conformable (así entendido: el contenido) en deseos, angustias e ideas de la esfera de la vida social, del ámbito público; pero este material es siempre tan complejo y contradictorio, tan diversamente valorable y elegible, que necesita de la aplicación y de la fuerza conformadora derivada de las inclinaciones individuales para poder convertirse en base del comportamiento.

La pregunta sobre cómo decidir cuál de los dos es más fuerte y valioso resulta irrespondible. Para muchas naturalezas y - lo que no se puede olvidar- en muchos momentos, la presión de la publicoidad es tan poderosa que apenas si queda huella de la peculiaridad privada. Pero a la hora de estimar el grado de capacidad de oponerse hay que atender también, y mucho, al terreno de la actuación. Unos sucumben con facilidad a la presión política; otros, más a la religiosa, científica, artística o erótica. Los puntos de penetración de las influencias son múltiples y dependen, en parte, de la especificidad del hombre $\mathrm{y}$, en parte, de las corrientes recognoscibles históricamente y del carácter del pueblo. El proceso de transformación, en el alma de cada individuo, del material tomado de lo público, en ocasiones se parece al proceso químico intensivo que tiene lugar cuando se calienta mucho algo; en ocasiones, al calentamiento suave en el fuego de la cocina de la familia.

Finalmente, hay que atender a una circunstancia cuya consideración resulta importante a la hora de aclararnos tan complicada interrelación: lo público puede destruir mucho de lo individual; puede cambiarlo, debilitarlo, quitarle fuerza; pero nunca puede apagar y dejar de lado todos los rasgos de su ser. Puede desplazarlo de un campo a otro, despojarle en ciertas circunstancias de todo valor, convertirlo en accidental, inocuo y desvalido. Pero lo privado-particular huye siempre a rincones que pueden parecer sin importancia a la consabida publicoidad. Hasta en profesiones en las que, de acuerdo con la tarea correspondiente, las personas tienden con fuerza a igualarse interna y externamente — como las de oficial, estudiante, clérigo_-, las diferencias de gesto, actitud y manifestaciones temperamentales no desaparecen del todo. Por el contrario, las cualidades personales medran tanto más copiosamente allí donde no se trata de nada importante para los fines del grupo. Sin duda, la propia oposición entre las exigencias profesionales igualatorias y los hábitos personales hace que en estas esferas precisamente lo autónomo individual choque más que de ordinario. Así, las diferencias entre sus profesores son a los ojos de los alumnos llamativas, hasta llegar a considerarlas como un surtido de originales de tipo diferente. De mis tiempos de cadete recuerdo que los educadores, casi todos oficiales, no nos parecían nunca como miembros intercambiables de un colectivo, sino como individualidades muy distintas y a tratar muy distintamente. Y no se trataba de una ofuscación de jóvenes inmaduros: realmente 
eran muy diferentes en determinadas propiedades. Las profesiones, asociaciones y colegiaciones reclaman uniformidad sólo en determinados campos de conducta o de pensamiento, exigen a sus miembros sometimiento a las normas que conciernen a su formación; pero se preocupan muy poco de lo que les es ajeno. Lo privado-particular no se deja eliminar del todo; tan sólo se lo reduce a bagatela.

Si queremos valorar comparativamente ambos dominios sólo cabe decir: como siempre, también aquí depende de la medida. Decisivo es lo que lo público reclama para sí, lo que relega o remite de nuevo a la privaticidad. Un exceso de lo público acaba generando una tendencia a lo privado; siempre hay hombres a quienes choca la desmesura y superficialidad de lo público, empujándoles a lo privado. Para ellos acaba siempre volviendo el tiempo del recogimiento, la exigencia de lo esencial que lo público no puede satisfacer. Como Schiller, se dicen: «escapa del tumulto de la vida al espacio quedo y santo del corazón». Pero, a su vez, la meditación y el cavilar solitario despierta la necesidad del trato con los hombres y su influencia; igual que Fausto se sintió impulsado a salir de las pútridas y sofocantes cloacas para, durante la Semana Santa, dar un paseo ya no sólo entre la naturaleza, sino también entre la gente.

\section{El sobrepoder de la public(o)idad}

Esta introducción general y abstracta requiere concreciones intuibles; vayamos a cuestiones concretas. Las afirmaciones hechas pueden estimarse hipótesis cuya constatación requiere, de entrada, que sean corroboradas por observaciones a partir de la llamada realidad. Por lo que a mí toca, me afecta sobre todo la problemática concerniente a la situación actual. Así, queda mucho por decir sobre profesión y privacidad, sobre la economía y el influjo del mercado, sobre Rusia y América, y sobre el crecimiento demográfico, cuyo influjo domina todo.

Consideremos, pues, la actualidad: en nuestro tiempo los intentos por matar la esfera privada predominan tan manifiestamente que, en verdad, se tiene el deber moral de reclamar mayor espacio para ella, saliendo al encuentro de la sobreestima de una publicoidad devoradora. Una vez más: se trata sólo de rechazar la exageración. Nada más alejado de mí que el querer participar en el maligno deporte de pesimista crítico de la cultura y gritarle al mundo que nuestro tiempo se encuentra bajo el signo de la decrepitud y de la decadencia espiritual. No hay, en absoluto, etapas del desarrollo que, en absoluto y en su conjunto, sean corruptas, malvadas, o estén tocadas de muerte. El tempo arrebatador, lo público en cuanto extensión del campo externo de las vivencias, como abundancia de rostros, como variabilidad, contiene un encanto estético y energías vitalizadoras. Se deja a un lado el eterno ayer envejecido. Lo público es vida, aire fresco, despliegue de fuerzas. Si existiera hoy un equilibrio armónico entre ambos campos, si el dentro y el fuera se completaran bien, no 
habría motivo de queja. Pero si, como quedó dicho, el exceso de lo público está despertando de nuevo la tendencia a lo privado, entonces semejante dialéctica necesita de críticos despiertos que se comprometan para que esa tendencia se haga realidad. Hay peligro de que lo privado se asfixie bajo el tumulto de lo público. Su predominio es hoy grande; tiene medios harto poderosos y le resultaría muy fácil aniquilar la privaticidad.

Lo que espanta en este predominio actual de lo público es que decide en exclusiva sobre la calidad de las realizaciones, sobre la gratificación, la fama y la supervivencia en el recuerdo de los que nos sucedan. Capacidades y talentos no son sino simples medios de encontrar el reconocimiento de esta autoridad decisiva. Es verdad que al joven marido le hace feliz el que su mujer le tenga por un genio o a los padres el ver a su hijo lleno de esperanza. Pero ¿de qué esperanza se trata?; ¿quién decide sobre la genialidad? Bien puede ocurrir que un enamorado reconozca honradamente: "¿qué me importa todo el reconocimiento del mundo?; sólo tu confianza me hace feliz». Mas ¿en qué se basa esta confianza? ¿Hasta cuándo podrá seguir afirmándose semejante dicha de la pareja si, fuera, el mundo falla? La mayoría de los padres, alegres por los dones de sus hijos, se imaginan ya a su muchacha, superdotada para la música, inclinándose en la sala de conciertos mientras agradece el caluroso aplauso; ya están viendo a su retoño, que promete ser un actor fuera de lo común, recoger por tres veces el «ibravo!» ante el telón. La campesina piadosa sueña con que su hijo, asombrosamente elocuente, sea párroco en su aldea. Estudiantes aplicados ponen los codos día y noche sobre los libros para pasar sus exámenes con sobresaliente y lograr buenos empleos. Una y otra vez, las dotes, la aplicación, lo que destaca se consideran como mercancía para el mercado público, con la esperanza de un buen precio. Pero iy el valor propio de las facultades, la satisfacción del trabajo en sí mismo, el goce de la creación, el enriquecimiento del yo! No es que falte. Pero se le desconsidera, se le empequeñece, se le acalla ante la atracción de lo público, de la gratificación material o de la fama: ser renombrado, aparecer en la prensa, en fotografías frecuentes, como una «estrella», ser caracterizado como "conocido» y, si es posible, como "famoso»: todo esto seduce demasiado. Pero no es sólo la codicia o la búsqueda de la fama lo que atrae en la vida social pública. A menudo es la amarga necesidad la que reclama ponerse a su servicio y sacrificar o recortar la satisfacción privada. Quien entre los pobres no quiera pasar hambre y malvivir en la miseria está obligado a no perder de vista lo que quieren los consumidores o los poderosos, los señores de la oferta: si y en qué grado les satisfacen las realizaciones de los dotados. Son las demandas del público, o, mejor, los intereses de quienes manejan ese público, los que deciden. Lo que cuenta es el fallo de los "prominentes», quienes a menudo se diferencian, con desventaja, de la verdadera élite y representan lo público. A menudo podrían responder al poeta que les ofrece su obra: «no ignoramos su talento, su ethos, su esfuerzo; pero el público rechaza la obra; lo sentimos». El poeta podría responder: «¿Qué público es ése? Sois vosotros mismos. Os creáis un fantasma, un ídolo. Y me enfrentáis vuestro egoísmo o vues- 
tra superstición.» En ocasiones, la astucia presenta al experto la salida de un compromiso entre las pretensiones de los que median ante el público y sus propias aspiraciones; como cuando, p. ej., un escritor como Balzac escribe parte para el mercado, parte para sí mismo, para su liberación interior.

Ahora bien, sería injusto y desconsiderado el que quisiéramos presentar indiscriminadamente las pretensiones de lo público como cualitativamente de poco valor, y las emanaciones de la personalidad como lo que siempre es valioso. Lo público actúa en ocasiones como una piedra de afilar que suaviza las irregularidades de espíritus enfermos o supratensos. Es una educadora enérgica y en ocasiones paciente. Cierto: es una cuestión abierta saber en qué educa, pero las más de las veces lo hace para rebajar inclinaciones excéntricas, la sobreestima del yo, y amortiguar la pretenciosidad y la falta de compañerismo. Un yo tan pagado de sí mismo no siempre tiene razón — ni ética, ni estética, ni política, ni científica - frente a lo público. Pone riendas a la hinchazón de una presunta genialidad, frena excesos de otras inclinaciones que, de no ser así, acabarían representando un peligro y hasta la decadencia para la persona misma y cuantos le rodean. No hay que desdeñar la influencia disciplinadora de lo público — de la escuela, asociaciones, ligas y empresas, sobre todo-, gracias a la cual se mitiga la tosquedad, la desconsideración o la crueldad. El yo privado se hace así contenido, disciplinado y civilizado. Su fiereza primigenia ya no estará en condiciones de hacer tanto daño.

\section{La fama}

Todas las consideraciones sobre lo público acaban resolviéndose de inmediato en investigaciones sobre sus distintos modos de actuar. Hay que saber de qué publicoidad se está hablando. Con frecuencia, una de cierto tipo de publicoidad nos protege de otra diferente; su acción curativa consiste justo en eso: en defendernos de sus corruptores efectos; ello vale sobre todo para el estado y la iglesia. Puestos a pensar en los peligros y sufrimientos de las profesiones liberales, en particular de poetas y artistas, a los que se exponen por su servicio al mercado, ¿qué podemos apuntar? Pues que los maestros oficiales del arte y la ciencia se ahorran no pocos de aquéllos precisamente por su mayor o menor sometimiento al poder público del estado o de la iglesia. En general, no es posible decidir qué es preferible, si la dependencia de la superioridad o del mercado; en ambos casos hay que sacrificar no poco de lo privado. Ni siquiera el eremita se puede librar del todo del látigo de lo público. Presupuesto que la soldada no sea demasiado parca, el estado protege al profesor de las humillaciones de la oferta mercantil; pero no le puede ahorrar ni curar las heridas conferidas a veces por los colegas o la crítica. Así, cuando un tipo de coacción pública se debilita levanta otro, aún más desafiante, su cabeza.

¿Y la fama? ¿Tiene razón Schiller: «de todos los bienes de la vida, la fama es el supremo. Cuando el cuerpo se reduce a polvo, el nombre ilustre pervive»?; 
¿o más bien Goethe, que le hace decir a Fausto, envejecido: «la acción lo es todo, la fama nada»?

Es lo público quien decide sobre semejante fama. Su arma más fuerte a favor o en contra del hombre que se afana es la seducción: te hago inmortal; vivirás en tus obras si te afanas con constancia a ellas. Te puedo levantar un monumento en la capital o un busto en el salón de fiestas. Tú no te apagas como una chispa en el fuego. ¡Qué breve es la existencia corporal! ¿Quieres hundirte en el rebaño de la mayoría, sin dejar huella, rápidamente olvidado? Qué atractiva resulta esta voz de esa administradora del recuerdo que es la notoriedad pública. Pero, también, cuán cuestionable es semejante inmortalidad terrestre. Vaya la cita del poeta Gottfried Benn (quien, es verdad, ama en exceso una forma de expresión exageradamente incisiva, pero que acierta a decir lo importante en su lenguaje de imágenes): «es patente que la fama y la genialidad no tienen que ver propiamente nunca con lo que se ha hecho, sino con lo accidental, con lo fatídico de la figura, lo exterior y lo interior. No es la obra como tal la que trae la fama. ¡Ay, si se piensa en la singular posición que adopta el colectivo! Mas en semejante circuito queda conectada la obra ${ }^{37}$. Es éste un tema muy tratado en la literatura del siglo XVIII; p. ej., por D’Alembert, Voltaire y, sobre todo, Lichtenberg; luego, en el siglo XIX, por Schopenhauer. Ya Lessing dijo, con amarga ironía, acerca de la publicoidad: "unos tienen la fama y otros la merecen ${ }^{38}$. Cabría sacar muchas citas de los Parerga y Paralipomena de Schopenhauer; en particular, del capítulo II: «de lo que uno se representa», y del XX: «sobre juicio, crítica, aplauso y fama». He aquí unas pocas citas: «desde el punto de vista eudaimonológico la fama no es sino el mordisco más raro y gustoso a nuestro orgullo y vanidad. Pero en la mayoría de los hombres, aunque lo oculten, ambas se dan en demasía; y con más fuerza en aquellos inclinados de algún modo a conquistar la fama; por eso las más de las veces tienen que soportar largo tiempo la conciencia insegura de su singular valía antes de que llegue la ocasión de probarlo y experimentar el reconocimiento de la misma: hasta entonces era una exigencia, como si sufrieran de una secreta injusticia». Y la preciosa nota al propósito: "puesto que nuestra máxima satisfacción estriba en ser admirados, pero los admiradores, incluso si se dan todas las causas, no se dejan arrastrar a gusto, el más feliz es aquel que, como sea, logra admirarse sinceramente a sí mismo. Sólo que los demás no deberían desorientarle». Schopenhauer, por su parte, valoraba en muy poco la fama entre contemporáneos: "pues — dice_ los hombres, por regla general, no tienen juicio propio y ninguna facultad para apreciar las realizaciones elevadas y difíciles; se guían siempre por la autoridad ajena; y la fama, en su grado más alto, descansa en un noventa por cien de los casos simplemente en la lealtad y

37 Cfr. Gottfried Benn, Provoziertes Leben, Ullstein-Bücher, pp. 63 y 65: «Das Genieproblem».

${ }^{38}$ En la edición de sus Gesammelte Werke, Wiesbaden, 1946, Brockhaus, 5 vols., pp. 424 y 426 . 
la fe»; quiero señalar que mientras a la fama contemporánea le juzga pesimistamente, con razón, tiene demasiada confianza en la fama de la posteridad. Pretende decir que: «según esto, tan dífícil es alcanzar la fama como fácil conservarla. En realidad la fama no puede perderse nunca, pues la acción o la obra por las que se consiguió permanecen firmes para siempre; la fama por la obra queda para el primero que la erigió, independientemente de que aquélla se renueve. Pero si la fama efectivamente se extingue y pasa de moda era inauténtica, inmerecida, surgida de una sobreestimación momentánea» ${ }^{39}$.

Me parece que estas afirmaciones contienen una esperanza desmedida, procedente de un tiempo piadoso que ni siquiera hoy queda olvidado tan rápidamente; en nuestros días son cuestionables. Es verdad que nos preocupamos más que antes en festejar el retorno del calendario con los días del nacimiento y la muerte de los «hombres famosos». Pero acontece como si se recordara este deber, cuasi burocrático y de acuerdo con un patrón, con desasosiego, para volver a olvidarlo más a fondo aún ante la desaparición de la fecha premonitoria. Si el calendario no despertara a los cronistas reinaría el silencio. Añádase que quien es famoso en una época puede ser tanto más olvidado en la próxima, incluso desestimado. ¿Hay que dar ejemplos? Son inagotables.

De hecho, los elogios o vituperios de la historia del arte y la literatura, todo el rango de políticos y descubridores, de profetas y sabios, no refleja directamente la jerarquía de las realizaciones, difícil de establecer con toda justicia y adecuación; más bien depende de una escala de valores tenida por válida, pero históricamente condicionada por las necesidades, las apreciaciones dominantes y el arte retórico de los críticos. La notoriedad pública es corta de vista, favorece, perjudica, prefiere: es partidista. Con el tiempo se corregirán muchos juicios. No será raro que lo que no vale nada halle reconocimiento y lo excelente se desconozca del todo, aunque a menudo sólo en grandes lapsos de tiempo. Pero muchas cosas con valor se hunden pronto en el olvido; los pequeños defectos que se encuentran junto a grandes virtudes olvidadas se exageran indebidamente; la envidia, el veneno más extendido en las relaciones entrehumanas, arrasa con los méritos. No poco permanece en el olvido y el desconocimiento, simplemente porque no corresponde al gusto y a la moda. ¿Qué está justificado en los veredictos de la opinión pública? Hasta los monumentos en mármol y granito serán derribados un día, en cuanto cambie el sistema político. ¿Quién es en realidad éste?, se pregunta la muchedumbre ante muchas estatuas, si es que se ha fijado en ellas siquiera. En cuanto a la historia de la literatura, una vez escribíi ${ }^{40}$ : «no hay rama del saber como la historia de la literatura, cuyo cultivo sea tan necesario para el entendimiemto del desarrollo espiritual y que, a la vez, esté, para lo que tendría que ser, más plagada de imperfecciones.

${ }^{39}$ Cfr. Parerga und Paralipomena, 1 tomo, p. 243, Wiesbaden, 1946, Brockhaus, 1 vol, p. 423.

${ }^{40}$ Cfr. artículo «Soziologie», en el Handwörterbuch der Sozialwissenschaften, entrega 10, p. 637. 
Tómense sin prevención la mayoría de los escritos sobre la historia de la literatura: se tendrá la impresión de estar asistiendo ante un tribunal en el que se enjuician, sin piedad y sumariamente, todos los presuntos pecados contra el espíritu; la mayoría de ellos son perdonados sólo y a lo sumo atendiendo a circunstancias atenuantes; muchos son condenados a pena de eterno olvido». $\mathrm{Ni}$ que decir de los políticos. Su caracterización oscila siempre en la historia.

Sin embargo y pese a lo dicho, la fama es uno de los medios de seducción más fuertes para ponerse al servicio de lo público. Son pocos los que no se inclinan ante ella y no extraen de sus juicios la fuerza de su autoconciencia. Precisamente los más grandes oscilan entre el convencimiento de que la acción lo es todo, la fama nada, y la confesión de que ésta es el supremo bien de la vida.

En especial para los hombres esforzados, enérgicos y a la vez dotados que proceden de medios familiares o profesionales cerrados, el gran mundo exterior y la atmósfera de la vida pública que les llena constituye un campo de liberación gratificante. La limitación de sus allegados, la eterna pequeñez de una cotidianidad dominada por preocupaciones materiales, genera en ellos una codicia de consideración y reconocimiento por parte de quienes siéndole ajenos se le antojan, sin embargo, decisivos. Les atrae el escenario, el feuilleton, la radio, las embarcaciones, el extranjero, la legión extranjera; todo esto es para ellos mundo, aire fresco que se aspira con delicia; la esfera privada les parece, en cambio, una cárcel, a lo sumo una guardería que les va ya muy pequeña. ¿Tendrán que, con todas sus dotes, anquilosarse en la estrechez y el vacío? Pero lo público es como Circe: cumple poco de lo que promete. Pero por muchos desengaños que la vida pública les reserve, en comparación con las pobres relaciones privadas se les antoja una zona de libertad. Es un privilegio y una ventaja para la juventud audaz confiar en ella más de lo que le corresponde. El propio reino de lo público tiene sus máximas ventajas gracias a la bella locura de los inexpertos; en ella confluyen energías y dones; de lo contrario se pudriría y acabaría muriéndose.

Entre lo público y las personas dotadas se da, hasta cierto punto, una relación de oposición. Alcanzada la meta con los tambores del reclamo, y cuando lo público se dispone a aceptar sus talentos, garantiza a los así reconocidos ayudas (a veces considerables; como reza el dicho: allá vuelan las palomas donde las hay). Felicita al receptor y multiplica así su esfuerzo por gustarle y dejarse conducir por él. Cada vez con mejor disposición atiende el favorito a los deseos de los anuncios y la propaganda, a todos los medios, hoy tan refinados, de aturdimiento y retórica. Se necesitaría estoicismo y voluntad ascética para no sucumbir a la tentación. Podemos traer a colación ejemplos tomados de la historia más reciente que muestran qué cambios se dan en la mente y los juicios (y en su expresión literaria), incluso en los principios políticos y éticos, en muchas personas bien dotadas, tan sólo para no perder el favor del público.

Pero tampoco tenemos que ser demasiado estrictos e hipócritas a la hora de juzgar. La desestima, el pasar desapercibidos y desconsiderados resulta muy 
duro; frena la capacidad de ejecución. Aparece la dolorosa sospecha sobre la propia competencia: ¿tendré que resignarme a quedar efectivamente por detrás de aquellos de cuya menor valía estaba convencido hasta ahora? ¿Por qué no hablan sobre mí, mientras se elogia sin cesar a semejante sujeto? Con tales reflexiones, emerge la incertidumbre de si estará uno en el camino acertado. No es que sea un camino malo ni exento de valor; pero no se trata, desde luego, de una gran avenida; por tanto, se intenta cambiar; ¡también esto es posible!

El espíritu de cuerpo, de nuevo en ascenso hoy; la organización gremial y, sobre todo, la clique hacen muy difícil el abrirse camino. Abunda por doquier la idea de que nadie puede imponerse particularmente por sus propias fuerzas, de que se requiere una adhesión a los colegas. Por lo que también las profesiones «liberales»: escritores, artistas, eruditos, deberían hacerlo. De inmediato se alza ese instrumento, en otros tiempos casi exclusivo, del espíritu corporativo: «Paz dentro; guerra fuera!». Nadie extraño, que no esté marcado por aquél, tiene acceso al grupo. Puede que a algunos les resulte difícil renunciar a las ventajas de la autonomía y la singularidad individuales, tener que soportar como iguales, entre los camaradas organizados, a chapuceros y mediocres; en tal caso se le pide que, por lo menos, no ose concurrir con nadie que sea ajeno y no esté organizado. El predominio de la clique en todos los ámbitos de la vida social se detecta por doquier. ¡Qué difícil lo tienen entre nosotros los estudiosos privados! $!^{41}$. Basta ver cómo se unen periódicos, revistas y editoriales con determinados círculos de la literatura y el arte, excluyendo a los otros. Añádanse otras circunstancias: órganos publicísticos que ni mencionan ni recomiendan obras de los no agremiados, inexistencia de un areópago que, sin acepción de personas, se pronuncie con rectitud en cuestiones especializadas; el resultado es una constante selectividad en parte falsa. $¡ Y$ ay de aquel que perteneciendo, según la ordenación al uso de las profesiones, a un círculo distinto no sea suficientemente modesto para contentarse con el rincón del sector prescrito! Le gritarán: «izapatero a tus zapatos!»; y ello aunque se puede mostrar cómo justamente los «diletantes» aportan no pocas novedades y piezas maestras.

\section{La profesión}

En conjunto puede afirmarse que, en nada como en la esencia de la fama, se muestra con mayor claridad la complicada imbricación de lo público y lo privado. Basta observar, para comprobarlo desde un punto de vista histórico, cómo cambia el influjo de la notoriedad pública (Publizität).

Junto a ella nos ocupará ahora y aquí el concepto de la profesión y la actitud ante ella. No podemos dejar de lado la complicada problemática de la pro-

${ }^{41}$ Cfr. Jurgen V. KEMPSKI, "Wissenschaft als freier Beruf», en la Kölner Zeitschrift für Soziologie, 6 Jahrg., Cuadernos 3/4, pp. 77 ss. 
fesión, sin desarrollar especialmente las cuestiones económicas con ella vinculadas. Pero nos atendremos en exclusiva al cruce de motivos que son determinantes a la hora de escoger una vocación y de profesar una actitud ante ella. Dirigiremos nuestra atención a la actualidad y al estado de cosas en la Europa central y occidental.

A menudo se plantea la cuestión de si el concepto de la profesión, como idea ética, no se ha transformado para la media de la población actual en una decisión meramente utilitaria. Según muchos, la idea de una disposición determinada por el destino ha sido sustituida por la de una «ocupación»: un cálculo sobre ganancias y pérdidas.

Podría pensarse que, para empezar, habría que diferenciar entre vocaciones superiores e inferiores, mecánicas. Pero ello puede equivocarnos. También en las profesiones del político, artista o estudioso, las consideraciones sobre la utilidad en dinero pueden ser tan determinantes para cada uno como los principios del idealismo moral. Hasta en la decisión de hacerse clérigo o entrar en un convento se entremezclan a veces convicciones religiosas con consideraciones utilitaristas. De otro lado, la profesión de un trabajador manual, de un campesino o auxiliar de la administración, puede estar inspirada por ideas sobre el deber y el sentido de la vida; su tarea puede desarrollarse dentro de una entrega generosa a su trabajo y a su valor social. También en las empresas y en el campo se dan un montón de actividades que enriquecen y satisfacen interiormente, aunque dificultadas por la monotonía, la división técnica del trabajo y la adscripción a trabajos específicos monótonos. Tan discutible es la idea de que, manual o espiritual, la «ocupación» nos domina a todos, como la concepción irrealista opuesta que ve en cualquier trabajo una llamada de Dios. No hay profesión que no plantee exigencias que fatigan, nos agobian y hasta pueden parecernos indignas. La mayoría espera impaciente que llegue la hora del descanso, del reposo nocturno o la distracción; sólo que nos inclinamos ante el deber y esperamos una gratificación adecuada a todas nuestras fatigas. Sueldo mayor y reducción del tiempo de trabajo son metas tan triviales como insoslayables de nuestro esfuerzo ${ }^{42}$. Pero en todas estas reflexiones, que podríamos alargar, sobre la profesión nos hemos limitado al aspecto privado; nos preguntamos acerca de las fuerzas que impulsan a la persona en su actividad profesional. Sólo indirectamente trasparecen aquellas que mandan sobre lo público. Los particulares se preguntan sobre las oportunidades de ascenso que les ofrecen las condiciones del mercado laboral y de la concurrencia. El ámbito público es comparable a una tía de la que heredar: se espera de ella cierta generosidad, no que colme nuestros deseos esenciales. Pero aun cuando nos limitáramos a interrogarnos sólo sobre la persona que no se preocupa más que de sí, sería falso pasar por alto que hombres maduros, de amplias miras y honestos no se tuvieran también por servidores del estado, la iglesia, el pueblo o la

${ }^{42}$ Cfr. Harriet Hoffmann, Beruf und Privatleben, Institut für Wirtschaftspolitik an der Universität Köln, Cuaderno 2, 1954, pp. 46 ss. 
comunidad cultural. Se preguntan: ¿qué exigencias pueden y deben plantearme estas comunidades; cómo puedo yo contribuir de la mejor manera posible a su bien y a su perfeccionamiento? La actividad profesional es para ellos el campo al que consagran todas sus fuerzas. Su lema es: "patriae in serviendo consumor!». Ser útiles a otros, limitar su necesidad y su miseria, hacerles felices con sus tareas, son motivos que no han desaparecido por completo del mundo. Pero se han hecho más raros, chocan constantemente contra mil obstáculos, desconfianzas e incredulidad. El bienestar creciente, el espíritu calculador que se viste de prudencia, de filosofía "práctica" de la vida, se cruzan en el camino. Familiares avispados se dirigen, con sonrisa despectiva, p. ej., al joven muchacho: "no serás tan tonto que te vas a arruinar por otros» (para estas gentes, desprendimiento no es sino estupidez).

Pero aparte los quereres individuales que circunscriben el fenómeno de la ocupación con lo público, tenemos que ocuparnos de la publicoidad misma y sus pretensiones: no ya como mero objeto de las expectativas y temores de las personas, sino como una suprapersona con sus propias aspiraciones y preceptos. No en vano teme el pequeño yo su poder.

Las corporaciones públicas no podrían sostenerse si no existieran profesiones a su servicio; si no dispusieran de medios y caminos para alcanzar, por la presión social sobre hombres y grupos, lo que parece necesario socialmente a sus funcionarios. No pueden dejar la elección y los requerimientos profesionales al mero juego de las fuerzas, a la casualidad de las preferencias y los deseos, a los intereses privados; más bien crean una ordenación de las profesiones, dan leyes, ordenanzas y estatutos, regulan las posibilidades de promoción dentro de una jerarquía profesional; crean destinos y sancionan el ámbito de lo burocrático. Para ello se dejan guiar por la utilidad pública; la persona es para lo público un medio para el logro de fines, y la valora según la utilidad que aporta al conjunto. No basta con llegar a un compromiso entre las demandas privadas y las exigencias públicas, compromiso que, según la época, se inclina más en una dirección o en otra; deberían ponderarse en ambos dominios las aspiraciones del otro. Las personas no atienden en exclusiva a sus preferencias si quieren lograr sus metas, sino que tienen en cuenta los requerimientos del poder social. De igual modo el estado, las comunidades, uniones, empresas o cooperativas no tendrán plenamente éxito si ven a las personas como meros miembros suyos pero cuyas inclinaciones les son indiferentes. Y así como los intereses públicos embeben las consideraciones privadas, así los requerimientos de las corporaciones estarán influidos por consideraciones sobre los deseos y temores de la persona.

Vuelve a imponerse en la praxis la tarea de constituir una relación armónica y de no incurrir en ninguna unilateralidad. En la actualidad más reciente hemos conocido notables trastornos en este equilibrio. En Europa, y en Alemania no donde menos, el poder del estado se debilitó considerablemente tras la guerra y sus consecuencias; pero no en beneficio de la persona particular, sino en ventaja para las asociaciones más destacadas de intereses de todo 
tipo; asociaciones que representan mayormente el peso o la importancia de sus miembros constituidos como grandes grupos. La persona ha cambiado sus señores; en sus decisiones (no tanto en las iniciales opciones profesionales cuanto en su conducta en la profesión) se orienta mucho más hacia este tipo de publicoidad, representada por su "asociación», que a las pretensiones del estado. El polifacetismo de lo público ha crecido: la esfera de lo profesional se he convertido, prevalentemente, en un dominio dirigido y dominado menos por el estado que por asociaciones profesionales. El verdadero mal de nuestro tiempo es el egoísmo de grupo, que tiraniza a la persona tanto como las grandes corporaciones abstractas, pues aquellas asociaciones no tienen otro Leitmotiv que el esfuerzo por sus propios privilegios.

No es raro achacar al estado la responsabilidad en el retroceso de lo privado en nuestro tiempo. Esto era justo en tiempos del nacionalsocialismo; pero a este propósito hay que advertir que no debe entenderse por tal el espíritu tradicional que señoreaba al Reich alemán antes de las dos guerras y que, con todo el centralismo que se quiera, mostraba muchos rasgos liberales; no: fue el desenfreno de una tiranía apoyado por un Partido el que se apoderó del estado y le convirtió en la imagen hecha añicos de la cultura. Así querría entender yo las palabras de Friedrich Sieburg cuando escribe: «La conducción totalitaria del estado ha eliminado tan profundamente la frontera entre lo privado y lo público que todavía no es posible volver a dibujarla. La superioridad llegó a tal grado de endiosamiento que ya no toleraba ningún ámbito ni rincón personal al que el súbdito pudiera retirarse; hoy es el propio súbdito quien no desea la reocupación de estas zonas recuperadas para la libertad: ni tiene conocimiento alguno de sus derechos ni tampoco codicia, en el fondo, saber mucho de ellos. Cayó el viejo yugo: era malvado y mortal; se le sentía tal y se era consciente de su carga. El nuevo yugo ya no es advertido en realidad por nadie. Lo que nuestra mano debilitada ha desenterrado nos lo ha arrebatado el estado y lo manipula. Donde el hombre retrocede avanza el estado. Desde el 1914 han crecido tanto sus tareas en lo social y lo económico que ha tenido que cambiar su esencia para poder dominarlas. Querer obrar y pensar por los particulares se ha convertido en su segunda naturaleza. Anteayer fueron las imposiciones de la dirección de la guerra, ayer las amargas exigencias de la planificación social y económica, hoy la "cultura" y la "formación de la opinión"; mañana será nuestra vida privada el objeto de su solicitud y su empeño superiores. ¿Quién quiere hoy todavía defender su intimidad?; ¿quién siquiera es consciente de que está amenazada? Trozo a trozo estamos entregando lo que antes constituyera la soberanía del hombre occidental. La esfera privada otrora rodeada de una cierta sacralidad se derrumba. El hombre se retira de un campo tras otro; no se puede pedir al estado que no ocupe el lugar vacío que ya no podemos llenar con nuestra persona» ${ }^{43}$.

De todas estas manifestaciones lo que me parece más destacable es que el

${ }^{43}$ Cfr. Lust am Untergange, pp. 80 ss., Hamburg, 1954, Rowohlt. 
«súbdito» ya no quiere volver a resucitar la esfera privada. Apenas si advierte el yugo de lo público; espera del estado que actúe por él; configurar una vida privada fuerte, libre y rica en contenido requiere, en efecto, sentido de la responsabilidad, personalidad y autonomía. No es menos cierto que, junto a una mayoría de semejantes súbditos, se encuentran también, sobre todo entre los intelectuales, personalidades singulares que han sacado de los acosos de nuestra época la conclusión opuesta: la huida a la tan citada "torre de marfil», el aislamiento que apenas si se entera de lo público y se entrega al culto del yo. Me parece, sin embargo, que a propósito de las observaciones de Sieburg habría que matizar: se trata menos de la fuerza central del gobierno, encarnación del verdadero poder, acosando de mil maneras y por doquier, que de las asociaciones de intereses que se sirven del estado y utilizan en beneficio propio su aparato legislativo y administrativo. El estado adquiere así una seudoimportancia que no ha pretendido. La fuerzas públicas penetran en los rincones que la mortecina vida privada ha abandonado.

La debilitación del estado, de una parte, y el cautiverio de los particulares, por otra, son los defectos del mundo euroamericano. Lo que traslada nuestras esfuerzos al contexto político: dos poderes ciertamente bien contrapuestos, el americano y el ruso-soviético, tienen en común que cada vez dejan menos espacio al desarrollo específico de lo particular-privado. Es cierto que existe una gran diferencia en los caminos emprendidos por ambos. Y se trata de intenciones absolutamente distintas; en la Rusia soviética y su esfera de influencia: el sacrificio conscientemente programado de la persona y su autonomía más íntima; a eso se le llama el comunismo (lo que todavía hoy se da sólo en parte); en los Estados Unidos y los pueblos que imitan su modelo: la mencionada enajenación voluntaria del yo, su especificidad y particularidad, que en la vida pública no puede zafarse del estado. A un lado, el espantoso ideal de extinguir la autonomía de la esfera privada, convertir al hombre en un robot sin atisbo de iniciativa, de manera que ya no sea sujeto sino objeto. Es la meta de colectivistas y tiranos. Quienes no han sucumbido del todo a la locura dominadora y no se sienten aún en peligro, todavía logran entender a ese hombre que inocentemente y de buen grado se somete a semejante liderazgo y que no pretende sino su seguridad material; es posible que se hagan una idea de la felicidad humana general, a crear por ellos, más inofensiva aunque de tipo inferior; sobre todo al principio de su carrera, los ideales de emancipación de la explotación, la desigualdad y la injusticia pudieron no serles extraños. Pero aquellos que lo que pretenden es hacerles felices nada temen tanto como el trabajo autónomo de su cerebro, la actividad del espíritu entregado a sí mismo. Les ven como un laboratorio de ideologías que les son hostiles, y de revoluciones. Por eso, entre los colectivistas, los radicales buscan crear y consolidar un sistema de todo tipo de medios que se adentre, debilitándolo y destruyéndolo, en ese mundo de ideas y sentimientos, hasta hacerlo inactivo. Los imitadores menos tiránicos toleran un ámbito de crítica que se les antoja inocuo, el de la propia vida familiar; ven complacidos que la horda de estos "patanes» se goce 
en su apasionada existencia; pero no dejan de vigilar a los que piensan críticamente. Quien considera la dignidad humana en su autonomía interior no puede por menos de rechazar semejante procedimiento. Habría de ser una existencia sin preocupaciones económicas (lo que hasta ahora está muy lejos de acontecer para la gran mayoría del pueblo) y no pasaría de ser totalmente vacía, sin sentido y sin dignidad. Que el yo sacrifique su capricho al bien común no deja de ser educativo y, en ocasiones, gratificante; hasta puede alcanzar con ello un valor superior. Pero semejante sacrificio deber ser resultado de una evolución interior libre y de la fuerza de convicción de un camino abierto por uno mismo y no de la impuesta por un adiestramiento exterior. Permítaseme recordar lo que dije antes sobre una cierta tenacidad del modo de ser individual. Ni siquiera en el colectivismo extremo de Lenin y Stalin es posible apagar por completo toda especificidad personal; se la puede expulsar únicamente de zonas política y económicamente importantes. Todavía hoy se encuentran, entre campesinos y trabajadores rusos, individualidades empequeñecidas. Y también en un koljós sería sin duda posible hacer hoy estudios sobre este asunto. Se observa una individualidad castrada, relegada al lugar donde el colectivismo la tiene por inofensiva. La individualidad que se mantiene en una oposición acechante, intencionadamente oculta y cultivada en secreto, merece una apreciación diferente; aquí en lugar de la entrega simulada y el acomodo a la generalidad se cultiva soterradamente el desvío de ella, una actitud especial, privada y silenciosa.

Este camino de la coacción social, mediante el que lo público (la presunta liberación del proletariado) vence sobre lo privado en la Unión Soviética, es totalmente opuesto al procedimiento mediante el que en América se impone la inclinación a la publicoidad. También en este caso el resultado es el empequeñecimiento de la privacidad. Aquí es la técnica la que asume la tarea destructiva. El tráfico loco, la televisión, la fuga ante la soledad, la inclinación a mostrar en público los secretos de la esfera privada, el desvele de la intimidad, las exhibiciones deportivas en masa, la entrevista, las encuestas de opinión, la husmeación de los más retraídos, la banalidad de reporteros y fotógrafos, la afición al cine, todo ello y mucho más destruye la privacidad. Son medios publicísticos que no están al inmediato servicio del estado ni, la mayor parte de las veces, persiguen fines políticos; semejante tipo de colectivización es ciertamente contrapuesto al ruso-soviético. El dominio como meta política no se logra aquí mediante la sumisión a la voluntad de uno o de pocos jefes, ni por el ordeno y mando, la intimidación o el encarcelamiento; se trata más bien de un sometimiento de lo privado a lo público querido a partir de las propias personas. Lo privado se va muriendo; una tras otra van desapareciendo las peculiaridades individuales, libremente, y a menudo sin dolor. Ya no parece ofrecer aliciente alguno. No es en el hogar soledoso ni en el bosque callado que se recorre a pie (¿quién camina todavía?) donde se encuentra lo «interesante», las sensaciones que siempre se hambrean; es en la calle, en el estadio, oyendo la radio, en los periódicos ilustrados, en las conferencias y congresos, en el avión. 
También esto es aniquilación de lo privado por lo público. No pasa porque se tenga la intención de aniquilarlo, con la hostilidad del colectivismo político; más bien es el resultado no querido del progreso técnico y, ante todo, del crecimiento de la población. En semejante mundo los hombres se reclaman de lo público. Se les antoja como una fuente de enriquecimiento existencial. Apenas llega a la conciencia lo que en todo ello hay de pérdida de la intimidad, la ternura, la sensibilidad, el apego, la auténtica religiosidad, la nostalgia de la fuerza y riqueza de la vida interior. Los latidos del corazón son apagados por el ruido del mundo exterior; se olvidan rápido; como ya no son ni auténticos ni naturales, nos acaban pareciendo mero sentimentalismo.

Pero debemos añadir de inmediato: sería deshonesto en extremo que los europeos afirmáramos con soberbia que todo eso es más bien propio de los americanos y que repugna a los hombres de nuestro continente. Es cierto que choca con la tradición espiritual de éste, pero no, ni mucho menos, con su actual mentalidad. Lo que, con regodeo, se llama americanismo no solamente lo imitamos entre nosotros, sino que, en ciertos círculos, hasta lo superamos; lo que del otro lado del océano Atlántico se explica por la historia colonial, por lo extenso de su territorio y por la configuración histórica de sus clases y estamentos, es en nosotros falta de cultura, actitud de pasmados y buscadores de innovaciones. Se abandonan demasiadas cosas valiosas a lo extraño que nos ciega externamente. Colocados entre los dos sistemas opuestos de dominio mundial, este y oeste, detectamos cómo estos extremos se entrechocan desconcertantemente; les es común la aversión a lo privado. Pero en América la orientación hacia un extra-yo técnicamente dirigido tiene, en muy buena parte, su base natural en las circunstancias geográficas e históricas; hasta cierto punto, el colectivismo ruso se fundamenta en las peculiaridades del alma eslava, sobre todo en su gran capacidad de sufrimiento y entrega; pero en Alemania no se dan semejantes presupuestos como para imitar más de la cuenta uno u otro estilo de vida. Deberíamos cultivar un estilo propio, útil para lo que viene, que conjugue armónicamente publicoidad y privaticidad.

\section{La economía del dinero}

Pero ¿no son tales intentos de aclarar las interdependencias y oposiciones, un tanto intrincadas, de ambos tipos de comportamiento construcciones mentales retorcidas y artificiales? ¿No deberíamos hallar las explicaciones de semejantes imbricaciones y variaciones en un elemento: la economía del dinero o, si complace más, el capitalismo? ¿Cómo es esto? Simplificando, la explicación sería del tenor siguiente: la posibilidad de hacer intercambiables, en una escala meramente cuantificadora, todos los valores mediante un solo instrumento de intercambio; volver completamente opaco, merced a concesiones de créditos, este sistema de cambio: todo esto tiene que llevar a la subordinación de la privacidad a todo tipo de publicoidad. Sólo poderes públicos, dígase sobre todo 
estados y bancos centrales, pueden regular y controlar unitariamente este tráfico económico. Si todos los valores se transforman en mercancías, las diferencias cualitativas, que juegan un papel significativo en la vida privada, disminuyen en favor de la escala pública de cálculo. Todas las grandes corporaciones, incluso los estados, tienen que doblarse ante semejante imperativo de la evolución. Las fortunas de las personas privadas son a la vez instrumentos de un orden financiero suprapersonal, también supraestatal.

Se puede replicar a tal argumentación: la influencia de la economía crediticia y monetaria, muy desarrollada, refuerza la tendencia al predominio de lo público; pero no la explica del todo. Este sistema de economía no pasa de ser un aparato técnico que sirve a tal desarrollo, le facilita y fortalece, pero no le crea. En general, no es posible decidir si promueve o daña la esfera de lo público más que a determinados intereses particulares ${ }^{44}$. Poniendo el acento en determinados. Pues dadas ciertas circunstancias el capitalismo es también un instrumento para potenciar públicamente la fuerza privada de los señores de las finanzas. ¿Y qué decir de las gentes de negocios pequeños y medianos?; gracias a su habilidad negociadora — rapidez, aprovechamiento de la situación, trucos-, pueden sacar conspicuas ventajas de la omnipresencia del capital en la vida social; utilizan a su favor particular ese instrumento de lo público que es la economía monetaria. Sólo en referencia a esta gente puede considerarse el tráfico cambiario general como un instrumento al servicio de intereses privados.

¿Y los demás? Basta recordar las consecuencias de la inflación para mostrar cómo la gran mayoría de la población puede convertirse en víctima de las manipulaciones en las instancias monetarias y, con ello, en lo público.

Tal vinculación a la economía monetaria no es sino una expresión, particularmente notable, de la dependencia del mercado de todos los productores. (En nada, por lo demás, se pone tan de manifiesto lo público como en el mercado.) Desde que, hace milenios, hay mercado dispone la humanidad de un lugar clásico de encuentro. En él desembocan los trabajos más o menos privados; de él irradian de nuevo hacia todos los círculos privados los efectos del comercio. Son precisamente las comunidades más liberales, quienes garantizan a las personas particulares el máximo de espacio, las que deberían garantizar mercados «libres», es decir: sin dirección de la superioridad. Pero con ello tan sólo se sustituye una forma de tutela por otra. El empleado o funcionario, en tanto regulador del comercio, no hace sino delegar parte de sus funciones en el comerciante. Pero, a su vez, éste en tanto regulador del mercado no puede, por lo general (y salvo monopolio), proceder según sus intereses privados, sino que es un instrumento de lo público. Cuanto más los mercados crecen y se multiplican, tanto más se desarrolla su forma específica de publicoidad.

${ }^{44}$ Cfr. L. V. WIESE, «Die leitende Eliten», Universitas, 10 Jahrg., n.o 3, marzo 1955, pp. 261 ss. 


\section{El crecimiento de la población}

Podríamos hacer responsables del actual estrechamiento del campo de lo privado a la técnica, al mercado, a la política. Pero hay una causa general que engloba y domina estas causas especiales: el crecimmiento de la población. Cuantos más hombres viven juntos por kilómetro cuadrado, más público.

No se puede ahora desarrollar toda la rica problemática del crecimeinto de la población. Desde Süssmilch y, sobre todo, desde Malthus apenas existe cuestión social tan debatida a lo largo de dos siglos como la de si el incremento de la población ha de tenerse por amenazador o gratificante. ¡Con qué aspereza no se ha vituperado y rechazado a Malthus por una teoría corregible en detalles, sin duda, pero tan rica de consecuencias en el planteamiento fundamental del problema! La mayoría de los populacionistas (de los alemanes muy en especial) tiene por máxima indiscutible que un pueblo no prospera sin una progresión, aritmética al menos, de su número de cabezas, y que el gran número de niños es una característica de la sangre nacional. En este tema los puntos de vista políticos, y en segundo lugar los económicos, han sido determinantes. Predominaba la idea de que una población es ante todo material al servicio de la concurrencia y lucha de los pueblos. Se prometía también, dadas las exigencias que un aumento fuerte de la población plantea a las capacidades y esfuerzos de los súbditos en la familia y las empresas, un aumento de todo tipo de producción y de la capacidad militar. Cuando los padres tienen que bregar por dos o tres hijos, difícilmente pueden ser presa de la pereza, la flojera y la concupiscencia. En el antimaltusianismo había demasiado de estrechez espartana o prusiana. No faltaron, por lo demas, hipócritas que reclamaban para los otros una fecundidad tenida por imposible para ellos mismos. Pocos mostraron preocupación y temor ante el acoso de las muchedumbres en crecimiento. Se hubiera podido mostrar cuánta tosquedad y desconsideración, cuando vacío existencial, podía explicarse a partir del inmenso número de "compatriotas». Es en la superabundancia de tantos y tantos donde radica al fin una de las causas capitales del ruido y la insoportable vorágine de las ciudades (hoy no sólo de las grandes); la tenacidad e inveracidad de la concurrencia, el tempo hiperrápido, el desvío del interés por metas verdaderamente valiosas hacia el ajetreo del mundo exterior.

Pero no es ahora ocasión de desatar los embrollados nudos de semejante estado de cosas. Tampoco querría caer en la falta de los propagandistas de una idea que lo derivan todo de una circunstancia (de hecho e intencionadamente dije que el aumento poblacional era una causa capital, no la única). Pero apenas sabría nombrar otra causa de tan varias y hondas consecuencias. Ni hay por qué enumerar tan sólo hechos negativos o desfavorables. Tratándose del número tampoco hay que olvidar lo cualitativo. Nunca sería bastante abundante la descendencia de hombres valiosos que crecieran bajo condiciones favorables y una educación correcta, y que no descendieran por debajo del nivel alcanzado por sus antecesores. Pero la masificación de los inferiores que 
se apretujan por doquier y crean una opresión asfixiante no puede por menos de verse como amenazadora. La ejecutoria total de un pueblo (cultural, económica, militar) depende más de la calidad que del número de hombres. El progreso técnico (de tan dudosa valoración en otros casos) se nos muestra aquí como benefactor en tanto el aparato muerto está en condiciones de sustituir al esfuerzo humano.

Sobrepasa nuestra tarea seguir entretejiendo tantos hilos. Bástenos destacar que cuanto mayor es el crecimiento de la población, tanto más domina la vida humana el principio de lo público. Cuantos más rincones de sosiego desaparecen, más crece la opresión de calles y mercados y tanto más fisga el vecino en ollas y alcobas; cuanto menos soledad, tantos más menesteres se convierten en tareas públicas. Ya empiezan los alemanes a viajar en grupos grandes, echando de los hostales a los que van solos; ya las representaciones de masas en los congresos y otros escenarios empiezan a sustituir a las conversaciones silenciosas y fecundas en pequeños círculos. Toda esta irrupción de las masas está causada, en definitiva, por el incremento de la población.

Parece ser una tautología perfectamente trivial: donde hay mucha gente se junta en grandes catervas. Pero hay diferencia entre reunirse en agrupaciones privadas, no organizadas, libres, no estampilladas por la publicoidad, o en grupos propiamente tales cuya característica fundamental es la organización. La privacidad repugna ser organizada; lo público, en cambio, no puede pasarse de ello. Nuestra tesis, por tanto, es: el simple aumento de la población requiere una organización creciente; esto es: ordenación en grupos según la división del trabajo y de las funciones. Y la organización es un principio de lo público, no de lo privado. Cuando se trata de un pequeño número de personas, que se ven cara a cara, la división del trabajo se limita a estipulaciones laxas; o es algo naturalmente dado, una relación asumida como evidente (caso del matrimonio y de las familias pequeñas).

Lo público es, justo, lo organizado; algo público no organizado se descompone rápidamente en puras relaciones privadas. Parecería que esto está en contradicción con la tesis implícitamente formulada antes, según la que las masas llevan a presiones tumultuosas: al desorden. De hecho, lo que desconcierta es su acción inmediata: el empuje multitudinario. Pero de inmediato surge el esfuerzo por dominarlo vía clasificación y división. Surge el conflicto entre multitud desorganizada y organización reglada. Entre nosotros los alemanes se exagera este empeño que lleva a la reglamentación y la burocratización; pero sería superfluo si no estuviera respaldado por la presión del número, tan grande como difícilmente abarcable. Se empieza por numerar. El hombre se reduce a mero número. El resultado es su ordenación en un esquema. No cabe consideración alguna suficiente de las diferencias individuales. Se es una fiera en la horda. Tal rebajamiento no se daría si se tratara de pocos; es la muchedumbre lo que conduce, de entrada, a él. En esa medida la fuerte multiplicación de la población es la causa última del predominio de lo público. 


\section{La tarea de la nivelación}

De todo lo dicho podríamos concluir con la siguiente cuestión: ¿qué hacer? ¿Debemos, tenemos, la posibilidad y la capacidad de fortalecer aún más el primado de lo público o volvemos al cultivo de lo privado? Pienso que semejante alternativa es rechazable. La decisión dependería de qué tipo de publicoidad o privacidad estamos hablando. De ello depende, asimismo, el que nuestra tarea consista en conformar la existencia de modo que ambos dominios (mejor: formas de comportamiento) se fecunden recíprocamente. Se trata, pues, de configurar aquellas ramas y aspectos de las dos esferas que tengan esta capacidad de estimulante fructificación. El aviso del filósofo griego: «vive en el retiro», no es recomendable sin más para todos los intelectuales; como tampoco la exigencia contraria: toma tu imperativo para el pensamiento y la acción sólo del requerimiento público; que muera, en cambio, en ti el del mundo secreto de tu interioridad y del pequeño círculo de los que amas.

¿Podemos denominar con toda concreción los ámbitos de la existencia que merecen estímulo y los que se debería evitar? Apenas es posible: porque son distintos según el tiempo y el tipo, porque lo que hoy es bueno puede ser dañino mañana, y porque lo que es recomendable para un país o una profesión puede fallar en otros lugares. ¿Qué significa, en general, ser fecundo? Se puede entender por tal simplemente una fuente de fuerza ética o estéticamente más noble y constante. Fructífero es lo que presta sentido a la vida individual y a la vez enriquece a la comunidad gracias a la simpatía, la disponibilidad y la apertura al nosotros y al vosotros.

Tratemos de actualizarlo de la manera más intuitiva posible con algunos ejemplos :

No se resuelve sólo con consejos particulares como: acortemos el tiempo de trabajo y alarguemos el de ocio, organicemos encuentros entre amigos, multipliquemos los días de permiso y festivos. Ello puede ser absolutamente merecedor de esfuerzo desde el punto de vista sociopolítico, asistencial e higiénico. Pero todo depende de para qué se va a utilizar el ocio, el permiso y las representaciones sociales. Cuando se introducen en la vida privada todas las exterioridades y patrones de la pública se manifiesta en aquélla uno de los males más terribles: el aburrimiento. En tal caso la esfera de lo público, agitada y arrebatadora, es el mal menor. Hoy, para muchos hombres vacíos, ocio equivale a lecturas de relatos de crímenes de mal gusto, a sesiones de películas del salvaje oeste y, sobre todo, al ojeo apresurado de periódicos ilustrados baratos. Se convierten en víctimas de especulaciones disparatadas sobre el gusto por lo sensacional de la multitud curiosa. En estas horas de ocio son todavía más simple mente público que en su trabajo; y en cuyo empobrecimeinto espiritual se empeñan día a día negociantes sin escrúpulos.

Pero también aquí queremos ser prudentes con nuestros prejuicios: no resolvemos nada con prédicas moralizadoras pedantes. No hay por qué ver sin más un indicio de total empobrecimiento interior en el hecho de que amas de 
casa más que fatigadas o gente de negocios echen mano de relatos criminales para relajarse y distraerse, u hojeen los modernos libros con dibujos para adultos; o en el hecho de que miles y miles se sientan atraídos por el júbilo frenético en el estadio durante un partido de fútbol. Todo es cuestión del tiempo que pierdan, del grado de entrega y de absorción. Hay personas, espiritualmente activas, que necesitan de un hobby inocente para mantenerse sanas; personas que no podrían pasarse del infantilismo de las ilustraciones para compensar la excesiva presión de su trabajo intelectual. No todos son así; para tales o cuales semejante tipo de relajamiento es un horror. Mientras tales inclinaciones queden dentro de los límites de lo tolerable, sería equivocado irrumpir entre las masas como predicador de cuaresma y reclamar el derrumbamiento de los desabridos dioses modernos; además, no daría resultado. Pero si sojuzgan a las almas, si hacen de la estulticia y el sensacionalismo una enfermedad del pueblo, el peligro es grande. Entonces resulta, en efecto, lastimoso para los hombres. En ese caso nos hundimos y nos hundimos.

¿Cómo cambiar semejante estado de cosas si con medios poderosos sólo se consigue lo contrario? Ni la retórica, ni la befa, ni la prédica son efectivos. Cuando las relaciones son más íntimas, el ejemplo de una manera de vida más rica puede producir cierto efecto. Pero básicamente sólo por dos caminos podemos buscar y alcanzar el cambio: configurar todo lo que arriba asignamos a la esfera pública de la manera más rica, interiormente activa y versátil que podamos; a la vez enriquecer la esfera privada cuidando la vida personal y mediante la constitución de pequeños grupos. Aquí se vinculan entre sí dos tipos de socialismo e individualismo (si vale usar semejante anticuada nomenclatura, y en la esperanza de que no se cuelen demasiados malentendidos por dar otro sentido a las palabras). Enumerar tales medios de animación sería peligroso; pues la cuestión en cada caso estriba en cómo se les use. Mal aplicados pueden producir efectos contrarios. Nada de aparecer como puntos programáticos formulados, de estar «organizados» ni de ser manejados por «líderes» o "reformistas» que se toman en serio y se las dan de pedagogos. Y, ante todo, que no sean medios de propaganda; tal abuso es siempre lo más fatal. Pero hay una cosa que no se puede silenciar: las leyes naturales y sociales que determinan la vida de los pueblos son más fuertes que la voluntad de benefactores bien pensantes. Ya vimos cómo el crecimiento de la población nos impone modos de vida a los que no podemos sustraernos. Un fanático del rejuvenecimiento cultural acaso deseara que volvieran a vivir entre nosotros no más de 30 hombres por kilómetro cuadrado. Pero ¿podemos, para alcanzar semejante meta, desear la furia ciega de la bomba de hidrógeno, la liquidación de millones y millones de hombres? Ciertamente, no. Pero entonces tenemos que asumir lo no poco malo de las apreturas. Sin embargo, hay que combatir el ciego sometimiento a una situación insuficientemente comprendida. Podríamos limitar no poca exageración insensata y denigrante. De lo que se trata es de conformar la vida social de modo que la zona de lo público garantice abundantes posibilidades de desarrollo autónomo de la personalidad, siempre que no 
ponga en peligro el bien común; y que, por su parte, también el ámbito de lo privado reciba estímulos y amplias visiones desde la esfera de los conjuntos sociales mayores. La llamada a una animación y enriquecimiento del contenido de la vida debería despertar solicicitud en ambas direcciones. La solución no tiene que buscarse en la entrega a uno de los dos «ismos» periclitados, individualismo o colectivismo; cuanto menos, en representaciones de los dos sistemas confrontados entre sí; más bien en un equilibrio de muchos principios y normas en el que se trataría siempre de no exagerar ni entregarse sólo a un propósito. El aliciente y la felicidad de la existencia individual, al igual que la prosperidad de las comunidades, estriba en una comprehensión de las vivencias no dogmática, abierta a todas las variaciones de la vida y que equilibre los valores.

\section{ANQUILOSAMIENTO Y PLENITUD COMO PRINCIPIOS FUNDAMENTALES DE DOS SISTEMAS SOCIALES}

\section{Dos necesidades contrapuestas}

Siempre y por doquier las comunidades humanas se hallan ante la difícil opción: o esforzarse por la unicidad, pero también entonces por el estancamiento y la parálisis; o por la abundancia en la diversidad, y con ello por el desorden.

Esta abrupta contraposición podría parecer exagerada; cabría recordar que la verdad estética y moral se encuentra en la unión de ambas normas; se podría y debería dar unicidad en una dimensión de la vida y pluralidad de aspectos en otra. En verdad, ello es un precepto de la experiencia y la prudencia. Pero los humanos están dominados por sus deseos y temores y conforman los preceptos de su voluntad de manera que las más de las veces les llevan a la exageración. Todo aquello que creen haber reconocido como justo y pertinente, y que está fuertemente influenciado por sus impulsos, lo elevan a dogma, a principio fundamental con la pretensión de generalidad y sin concesiones a otros modos de pensamiento.

En estas tendencias (a la unidad y a la diversidad), que dominan en la vida social, se ponen de manifiesto necesidades del ser humano. De un lado, hay que sintetizar lo que de otro modo se desparramaría y volvería en contra, aunque sólo fuera para, gracias a ello, poder alcanzar niveles más altos de fuerza. Se aspira a la disciplina, a la supra- y la sub-ordenación, a la coincidencia de esfuerzos, de mentalidades y pensamientos, a la unidad de fe y de ideales. De todo ello se sigue para los hombres en particular la ventaja de que, al estar incardinado en la gran coherencia del fuerte colectivo, ya no le concierne la responsabilidad de la propia decisión; al estar, en este sentido, interiormente socializado, puede tener una conciencia tranquila. No se le exige sino obediencia y dejarse llevar. No pasa de ser sino una célula en el gran organismo del 
constructo social; pero la sangre que recorre esta célula es la misma que mantiene vivo al cuerpo gigante en su conjunto.

La otra necesidad estriba en la circunstancia de que sin autodeterminación de los elementos no sólo el ser de estos elementos, el hombre de carne y hueso, se trueca en mecánico, en algo indigno y sin moral, sino que el propio constructo social se hace frágil: no puede prescindir de la voluntad transfiguradora, tendente al cambio y al mejoramiento; y semejante voluntad estriba sólo en el sentimiento de responsabilidad de las personas.

Las normas que los fundadores de religiones, los profetas, filósofos, moralistas, políticos, señores y caudillos imponen a sus seguidores, tan pronto sirven más a una tendencia como sirven más a otra. Hay esfuerzos que sólo sirven a la primera meta, la colectivización: aspiran a la conquista, al sometimiento, a la confesionalidad, la estatalización o el comunismo (descarado o enmascarado). El programa es unívoco, estrecho, simple, brutal y sin la menor consideración al bien y al dolor de cada hombre; a lo único a lo que atiende es a la sumisión sin rechistar. Las diferencias que puedan darse entre hombre y hombre se ven como obstáculos y, hasta donde es posible, se eliminan.

\section{La tendencia al tránsito de la tesis a la antitesis}

En teoría, es raro que se confiesen abiertamente tales metas; en la práctica (sobre todo en el trato de pueblos y clases) es más fácil constatarlas. Las teorías de la mayor parte de los caudillos de los pueblos y de la humanidad, aun cuando procuren la sujeción al colectivo, muestran elementos de la otra concepción: rasgos de humanidad, de entendimiento para un cierto grado de libertad; buscan hacer inteligible que la felicidad humana se encuentra en el duro camino por el que ellos marchan o proponen.

Por otra parte, quienes aspiran ante todo a la libertad, la paz y la fraternidad se encaminarán fatalmente por el carril opuesto. Precisamente porque quieren hacer felices a los hombres reclaman la difusión y la consideración general para sus teorías. Reconocen que, si no hacen todo lo que está en sus manos para hacer efectivas sus normas, surgirán y se les opondrán adversarios; y así se aniquilará su empeño por procurar la felicidad general. Se vincula entonces a su ethos emancipador la exigencia de difusión y, con ésta, la de una unificación obligada; se produce de esta manera, en la práctica, un cierto parentesco entre aquellos planes de los conquistadores y esta misión.

El ejemplo más manifiesto y trágico nos lo da el destino de todas las religiones, cuya historia ha conducido a guerras, luchas civiles y desgarro de pueblos. Similar fatalidad se produce en el desarrollo del socialismo: empezó con la doctrina creadora de la armonía y la liberación y ha llevado al comunismo forzoso. Ni siquiera el pacifismo, en cuanto tarea organizativa, escapa a tal maldición.

Quien más profundamente está imbuido de un ideal quiere luchar por él; 
quiere sacrificar no sólo a sí mismo, sino también a los demás. La consecuencia inesquivable de empeños de fuerte efectividad social es la exigencia de difusión, de victoria en el mundo entero. Pero el mundo no se deja expulsar voluntariamente de sus vías acostumbradas; ofrece resistencia.

\section{Liberalismo}

Hay sólo una excepción, rica en consecuencias, a esta ley de la historia de la sociedad y del espíritu: el liberalismo. Su variada y complicada historia está animada por el principio: garantizar a cada uno la autodeterminación y la autonomía, mantener en pie la plenitud de posibilidades sociales y evitar una difusión violenta. Pero en el angosto corazón del mundo europeo del siglo XIX no podía abrirse camino: porque se le asimilaba con los principios, emparentados pero no idénticos, de igualdad y fraternidad; y porque hacía a la mentalidad media de los hombres la siguiente concesión: sus principios, en definitiva y aun sobre todo, debían tener validez en el mundo de las preocupaciones materiales; de manera que la libertad, también o predominantemente, se interpretó como una ilimitación del egoísmo económico. Pero interpretárasele como se le interpretara, moralmente unas veces, materialmente otras, quedaba el principio: «que cada cual vea cómo se las entiende y que cada cual, allá donde se vea situado, que procure no decaer». En la práctica la consecuencia fue la diversidad y diferencia de modos de pensar sobre Dios y el mundo, sobre las metas de la existencia, sobre las relaciones entrehumanas y las agrupaciones. Se nos imputaron demasiadas cosas de lo que concierne a lo bueno $y$ a lo malo, a la riqueza $y$ a la pobreza, a la distinción $y$ a la rutina.

Quizá el éxito del liberalismo en Europa hubiera sido menor si los jóvenes Estados Unidos de América no hubieran pensado en convertirle en principio político fundamental y confiarle la defensa del estado. Con ello, sin duda, esta doctrina y práctica del dominio ideológico de la diversidad se aproximó también inevitablemente por su parte al principio del anquilosamiento y a lo rígido. Pero circunstancias históricas y geográficas particularmente favorables, así como una política exterior e interior de entendimiento, generaron un compromiso pugnaz, dentro del cual el principio de la libertad de movimiento se pudo, en general, mantener en pie. En definitiva, los americanos pudieron propagar por el mundo este principio y cargárselo a una gran parte de la humanidad que, dejada a sí misma, hubiera cedido ante la proclividad a caer en el principio del anquilosamiento.

\section{El mundo occidental y el oriental}

El resultado actual a escala de política mundial es conocido: un mundo occidental y un mundo oriental se enfrentan; allí la pluralidad, aquí el anqui- 
losamiento. Pero no es todo ni sólo felicidad para occidente por el hecho de que disfrute de una autodeterminación individual apenas combatida por poderes de política interior; acechan también peligros en el mundo liberal. Es portador no sólo de las ventajas del principo de la abundancia, sino también de sus defectos. En él se liberan una mentalidad de lucha por uno mismo, el esfuerzo moral y la simpatía libremente prodigada; pero también la astucia para la ganancia del hombre de negocios, el éxito del radicalismo de intelectuales excitados, la pigricia de los estultos. La cizaña y las hierbas venenosas pueden crecer a la par de la rosa y el abeto blanco. La abundancia de tipos humanos es desconcertante; resulta difícil procurar mayor validez a lo noble que a lo común.

Añádase a ello que en Alemania la situación es particularmente delicada. En la últimas décadas tuvieron lugar terribles desengaños y errores. La diversidad actual sigue de inmediato a un tiempo de acentuación extrema del principio del anquilosamiento y de la ligazón (Bindung). Año tras año hubo que ajustarse en Alemania a una política y a un orden social que consistía en la confrontación extrema de abundancia y autodeterminación. Dominaba la tiranía. Mucho de lo negativo se convirtió en regla para la praxis y para el pensamiento. Pero también no poco de lo malo, por contradecir al sistema dominante, fue ahogado junto con todo lo bueno.

A semejante unificación desertizadora le ha seguido la emancipación. No es de extrañar que muchos de esos hombres, intimidados unos y bellacos otros, no estén maduros para la autodeterminación. Más terrible resulta que se rompiera con ideales profundos que hubieran podido arrastrarlos y ennoblecerlos. Se ha quebrado demasiado. Las viejas directrices de origen religioso, político, filosófico o ético-social no pueden resistir a la duda de los que piensan; hay no poco que objetar a la demostración de aquéllas. Falta lo nuevo, lo esperanzador. Lo que hace todavía medio siglo desataba poderosas fuerzas espirituales, como las expectativas nacionales o los empeños político-sociales, se nos antojan ahora periclitados, muertos, pasados a la historia. El nihilismo filosófico, la enajenación del arte respecto de la belleza natural, la cientificación de la poesía, el pesimismo artificiosamente promovido, no se ajustan al íntimo dolor de los espíritus. La consecuencia es que los más rudos se entregan a los placeres de la vida más triviales; lo que es posible gracias al, por ahora, todavía rápido crecimiento del bienestar para determinados grupos de la burguesía y la clase trabajadora. La norma que se va extendiendo con rapidez reza: no pienses ni reflexiones. Goza hasta donde tu cuerpo te lo permita. Trabaja infatigablemente para multiplicar tus ingresos. Los propios dirigentes de la política económica dan la consigna: ¡mejora tu nivel de vida!; lo que no deja de recordar, con preocupación, a la que, tras Napoleón, se dirigió a Francia: enrichissez - vous!

Pero tampoco se debería enjuiciar con demasiado rigor esta ansia por el logro del bienestar; es el resultado lógico de las condiciones sociales; se desconfía del futuro; parece puro quijotismo querer trabajar por configurarle. Las directrices morales del pasado se tienen por vacías; y lo nuevo es insano, en 
exceso sofisticado y artificioso; espanta y no atrae. Por tanto: carpe diem, aunque con frecuencia de una manera muy superficial y externa, a veces desagradable. Y, sin embargo, se alza y florece una juventud llena de confianza y expectativas, cuya condición no muestra rasgo alguno del miserable culto a la nada. Exige directrices enérgicas y estimulantes.

\section{Los dos peligros para occidente}

Si se llamó la atención sobre el hecho de que el principio de la abundancia degenerara en indisciplina no fue para lamentarse o quejarse inútilmente, sino por dos motivos: crece el peligro de que Europa occidental, y en particular Alemania, vuelvan a someterse a la otra directriz de la unificación esclerotizante, ya que se abusa del principio de autodeterminación y se genera desorden. Segundo: hay que volver a hacer un uso justo de los mejores recursos de la tradición, precisamente para crear lo nuevo a partir de ahí. Pero no retomando viejos dogmas religiosos o filosóficos, sino sumergiéndonos amorosamente en muchas de esas fuerzas zarandeadas que pujaban ya por realizarse, sin que lo pudieran lograr satisfactoriamente porque las aniquiló de cuajo la brutalidad del principio del anquilosamiento.

(Traducido por José Joaquín RodRÍGUEZ-GonZÁLEZ.) 


\section{CRITICA DE LIBROS}

